\title{
The Stress-Induced Transcription Factor NR4A1 Adjusts Mitochondrial Function and Synapse Number in Prefrontal Cortex
}

\author{
- Freddy Jeanneteau, ${ }^{1}$ Christian Barrère, ${ }^{1}$ Mariska Vos, ${ }^{2}$ Carlie J.M. De Vries, ${ }^{2}$ CClaude Rouillard, ${ }^{3}$ Daniel Levesque, ${ }^{4}$ \\ Yann Dromard, ${ }^{1}$ Marie-Pierre Moisan, ${ }^{5}$ Vanja Duric, ${ }^{6}$ Tina C. Franklin, ${ }^{7}$ Ronald S. Duman, ${ }^{7}$ David A. Lewis, ${ }^{8}$ \\ Stephen D. Ginsberg, ${ }^{9,10}$ and ${ }^{\circledR}$ Margarita Arango-Lievano ${ }^{1}$ \\ ${ }^{1}$ Département de Neuroscience et Physiologie, Institut de Génomique Fonctionnelle, Institut National de la Santé et de la Recherche Médicale, Centre \\ National de Recherche Scientifique, Université de Montpellier, Montpellier, 34090 France, ${ }^{2}$ Department of Medical Biochemistry, Academic Medical Center, \\ University of Amsterdam, 1012 WX Amsterdam, The Netherlands, ${ }^{3}$ Département de Psychiatrie et Neuroscience, Université Laval, Québec City, Québec \\ G1V 0A6, Canada, ${ }^{4}$ Faculté de Pharmacie, Université de Montréal, Montréal, Québec H3T 1J4, Canada, ${ }^{5}$ Nutrition and Integrative Neurobiology, Institut \\ National de la Recherche Agronomique, Université de Bordeaux, 33076 Bordeaux, France, ${ }^{6}$ Department of Physiology and Pharmacology, Des Moines \\ University, Des Moines, Iowa 50312, ${ }^{7}$ Department of Psychiatry and Neurobiology, Yale University, New Haven, Connecticut 06520, ${ }^{8}$ Department of \\ Psychiatry, University of Pittsburgh, Pittsburgh, Pennsylvania 15260, ${ }^{9}$ The Nathan S. Kline Institute for Pyschiatric Research, Orangeburg, New York 10962, \\ and ${ }^{10}$ Department of Psychiatry, Neuroscience \& Physiology, NYU Langone Medical Center, New York, New York 10016
}

The energetic costs of behavioral chronic stress are unlikely to be sustainable without neuronal plasticity. Mitochondria have the capacity to handle synaptic activity up to a limit before energetic depletion occurs. Protective mechanisms driven by the induction of neuronal genes likely evolved to buffer the consequences of chronic stress on excitatory neurons in prefrontal cortex (PFC), as this circuitry is vulnerable to excitotoxic insults. Little is known about the genes involved in mitochondrial adaptation to the buildup of chronic stress. Using combinations of genetic manipulations and stress for analyzing structural, transcriptional, mitochondrial, and behavioral outcomes, we characterized NR4A1 as a stress-inducible modifier of mitochondrial energetic competence and dendritic spine number in PFC. NR4A1 acted as a transcription factor for changing the expression of target genes previously involved in mitochondrial uncoupling, AMP-activated protein kinase activation, and synaptic growth. Maintenance of NR4A1 activity by chronic stress played a critical role in the regressive synaptic organization in PFC of mouse models of stress (male only). Knockdown, dominant-negative approach, and knockout of Nr4al in mice and rats (male only) protected pyramidal neurons against the adverse effects of chronic stress. In human PFC tissues of men and women, high levels of the transcriptionally active NR4A1 correlated with measures of synaptic loss and cognitive impairment. In the context of chronic stress, prolonged expression and activity of NR4A1 may lead to responses of mitochondria and synaptic connectivity that do not match environmental demand, resulting in circuit malfunction between PFC and other brain regions, constituting a pathological feature across disorders.

Key words: dendritic spines; mitochondria; prefrontal cortex; pyramidal neurons; stress

Significance Statement

The bioenergetic cost of chronic stress is too high to be sustainable by pyramidal prefrontal neurons. Cellular checkpoints have evolved to adjust the responses of mitochondria and synapses to the buildup of chronic stress. NR4A1 plays such a role by controlling the energetic competence of mitochondria with respect to synapse number. As an immediate-early gene, Nr4al promotes neuronal plasticity, but sustained expression or activity can be detrimental. NR4A1 expression and activity is sustained by chronic stress in animal models and in human studies of neuropathologies sensitive to the buildup of chronic stress. Therefore, antagonism of NR4A1 is a promising avenue for preventing the regressive synaptic reorganization in cortical systems in the context of chronic stress. 


\section{Introduction}

Stress, especially when it is chronic and uncontrollable, produces depressive-like phenotypes and cognitive impairment in animal models (Krishnan and Nestler, 2011; McEwen and Morrison, 2013; McKlveen et al., 2013). Chronic stress impacts neuronal plasticity throughout the brain in part through excessive levels of glutamate and corticosterone (CORT) secretion that remodel dendritic territories in a manner that alters their functional properties (Pittenger and Duman, 2008; Popoli et al., 2011; Myers et al., 2014). Excessive levels of CORT impair neuronal sensitivity to serotonin and neurotrophins, resulting in reduced synapse number and neurotransmission (van Riel et al., 2003; Arango-Lievano et al., 2015). In hippocampus and cortex, chronic stress and CORT inhibit long-term potentiation (Kim and Diamond, 2002; Goldwater et al., 2009), enhance long-term depression (Xu et al., 1997), and produce dendritic atrophy, spine loss, and eventually cell death (Sapolsky et al., 1985; Radley et al., 2006; Liston et al., 2013; McEwen and Morrison, 2013).

Responses to acute and chronic stress are both considered adaptive to prepare for current and future demands, as they are paramount for survival (Karatsoreos and McEwen, 2011; Myers et al., 2014). The typical inverted U-shaped relationship between stress/CORT inputs and functional outputs (mitochondrial/ synaptic/behavioral) indicates that neuronal perceptions and responses to external signals are flexible to fit with network demands (Picard and McEwen, 2014; Sapolsky, 2015; Jeanneteau and Arango-Lievano, 2016). Neurons use their genomic and epigenomic arsenal to adapt their metabolism in accordance with their connectivity and network activity (Attwell and Laughlin, 2001; Gray et al., 2017). For instance, repetitive trains of excitation during seizures cause mitochondrial dysfunction leading, eventually, to neuronal death (Tang and Zucker, 1997). Modeling studies indicate that synaptic depotentiation is desirable to support neuronal survival when energetic stores are limited. Synaptic scaling changes mitochondrial functions in response to excessive/depressed glutamatergic excitation (Bindokas et al., 1998). Negative feedback mechanisms may have evolved to suppress synapse potentiation that would drain energetic stores upon glutamatergic overexcitation.

Checkpoints could lie in the genes that control signaling loops between mitochondria and synapses (Li et al., 2004; Jeanneteau and Arango-Lievano, 2016). Hundreds of genes are induced/ repressed in response to neuronal activity and stress, and, remarkably, each gene has a fine homeostatic pattern of expression (Valles et al., 2011; Datson et al., 2012; McEwen et al., 2015). These newly transcribed genes play important roles in many as-

Received Sept. 25, 2017; revised Nov. 10, 2017; accepted Dec. 8, 2017

Author contributions: F.J., S.D.G., and M.A.-L. designed research; F.J., C.B., M.V., C.D.V., C.R., D.L., Y.D., V.D., T.C.F., R.S.D., D.A.L., and M.A.-L. performed research; F.J., C.D.V., C.R., D.L., V.D., R.S.D., D.A.L., S.D.G., and M.A.-L. contributed unpublished reagents/analytic tools; F.J., C.B., V.D., R.S.D., D.A.L., S.D.G., and M.A.-L. analyzed data; F.J., M.-P.M., R.S.D., D.A.L., S.D.G., and M.A.-L. wrote the paper.

This work was supported by an INSERM AVENIR Grant (to F.J. and M.A.-L.); an FP7 Marie Curie Action grant (to F.J. and M.A.-L.); the Fondation pour la Recherche Médicale (to F.J. and Y.D.); and National Institutes of Health Grants 5P30-AG-008051-23 (to F.J.), and AG-043375, AG-017617 and AG-014449 (to S.D.G.).

R.S.D. receives support from Forest, Lilly, and Sunovion; and in the past from Johnson \& Johnson, Bristol-Myers Squibb, Taisho, Lundbeck, Asubio, and Sunovion. D.A.L. receives support from the BMS-Foundation, Merck, and Pfizer; and in the past from Bristol-Myers Squibb, Lilly, Merck, Neurogen, Pfizer, Hoffman-La Roche, Sepracor, and Wyeth. The authors declare no other competing financial interests.

Correspondence should be addressed to either Freddy Jeanneteau or Margarita Arango-Lievano, Département de Neuroscience et Physiologie, Institut de génomique fonctionnelle, Institut National de la Santé et de la Recherche Médicale, Centre National de Recherche Scientifique, Université de Montpellier, Montpellier, 34090 France, E-mail: freddy.jeanneteau@igf.cnrs.fr or margarita.arango@igf.cnrs.fr.

DOI:10.1523/JNEUROSCI.2793-17.2017

Copyright $\odot 2018$ the authors $\quad 0270-6474 / 18 / 381336-16 \$ 15.00 / 0$ pects of the adaptive abilities of the brain through the regulation of neuronal metabolism, dendritic growth, and synapse remodeling. We focused on Nr4al (Nur77/NgfI-B) because it shuffles among mitochondria, cytosol, and nucleus to modify metabolism (Zhao and Bruemmer, 2010; Pawlak et al., 2015), synaptic plasticity (Bridi and Abel, 2013; Chen et al., 2014), and cognition (Hawk and Abel, 2011; McNulty et al., 2012). NR4A1 has the necessary attributes to adapt mitochondrial functions and synaptic activity in the context of stress, as it is an activity-dependent immediate early gene responding to a variety of stressors and sensory stimuli (Chen et al., 2014; Helbling et al., 2014). Using complementary genetic approaches, we provide evidence for a causal role of NR4A1 in mediating stress/CORT-elicited dendritic spine loss in prefrontal cortex (PFC). NR4A1 acted as a transcription factor to change the expression of target genes previously involved in wasting the mitochondrial energetic budget and activating the AMPactivated protein kinase (AMPK) catabolic pathway (Steinberg and Kemp, 2009; Weisová et al., 2012). Inappropriate processing of this pathway during chronic stress, as opposed to acute stress, may lead to responses of mitochondrial function and synaptic connectivity that do not match environmental demand. As a result, stress-induced circuit malfunction between PFC and other brain regions may be a pathological feature across disorders (Sampath et al., 2017). This prompted us to validate results from animal studies to human studies of major depressive disorders (MDDs) and Alzheimer's disease (AD), as neuropathology in both diseases is aggravated by stress involving synaptic loss in PFC, disrupted CORT levels, and cognitive impairment (Lupien et al., 2009; Sotiropoulos et al., 2011; Heim and Binder, 2012).

\section{Materials and Methods}

All experiments were performed in accordance with the Directive by the Council of the European Communities (86/609/EEC) and approved protocols (00651.01) following institutional guidelines for the care and use of laboratory animals.

Reagents. Corticosterone, STO609 (CAMKK inhibitor), A769662 (AMPK activator), glutamate, oligomycin, and carbonyl cyanide-4(trifluoromethoxy)phenylhydrazone (FCCP) are from Sigma-Aldrich S.A.R.L. Doxycycline is from Clontech. Brain-derived neurotrophic factor (BDNF) is from Abnova. Tetramethylrhodamine methyl ester (TMRM) is from Santa Cruz Biotechnology. The antibodies used were as follows: cyto-NR4A1 (ABIN460855, antibodies-online.com); pan-NR4A1 (E6, Santa Cruz Biotechnology); and anti-human NR4A1 (D63C5), phospho (p)-NR4A1 (S350-P), ubiquitin (P4D1), P190A, phospho-acetyl-CoA carboxylase (ACC; S79-P), AMPK and phospho-AMPK (T172-P), HDAC2, and S6 (Cell Signaling Technology). Actin is from Sigma-Aldrich S.A.R.L.; FKBP51 and HSP90 are from BD Biosciences-Europe; GAPDH is from Thermo Fisher Scientific; and GFP and Drebrin (M2F6) are from Abcam. RFP is from Rockland Immunochemicals; PSD-95 is from NeuroMab; synaptophysin is from Thermo Fisher Scientific; and NR1 (ab1516) and NR2 (ab1548) are from Merck Millipore.

Rodent models. Thyl-YFP transgenic mice [B6.Cg-Tg(Thy1-YFP) HJrs/J; Feng et al., 2000] and NR4A1 knock-out (KO) mice (B6;

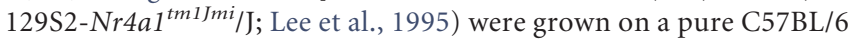
background. Time-pregnant CD1 mice (Janvier Labs) were used for in utero electroporation experiments. Frozen brain tissues from Nr4a1deficient rats (Nr4a1m1Mcwi) grown on a Fawn-Hooded Hypertensive background [Transposagen Biopharmaceuticals and the National Institutes of Health (NIH) Rat Knockout Consortium Program (http://www. transposagenbio.com/knock-out-rat-consortium)]. All animals were allowed ad libitum access to food and water and were maintained on a $12 \mathrm{~h}$ light/dark cycle. Males were used in all protocols. Chronic unpredictable stress includes one of the following daily random stressors for 10 consecutive days from postnatal day 21 (P21): wet bedding, no bedding, food deprivation, crowded cage, 2 or $6 \mathrm{~h}$ restrain, forced swim, shaking, $24 \mathrm{~h}$ 
light cycle, and tail suspension. Doxycycline $(2 \mathrm{mg} / \mathrm{ml})$ was administered via the drinking water and refreshed every $3 \mathrm{~d}$.

Tail suspension test. One-month-old mice were subjected to a single tail suspension test on the day before being killed. For habituation, the mouse tail was taped $5 \mathrm{~min}$ before suspension to a hook located in a $56 \times$ $40 \times 33 \mathrm{~cm}$ dark box. Frontal visual inspection of immobility postures was measured using a timer. Slight movements of hindlimbs only were also considered as immobility, as described previously (Can et al., 2012). Immobility in the tail suspension test (TST) is a typical measure of behavioral despair modified by long-term administration of CORT and chronic stress (Krishnan and Nestler, 2011).

In utero electroporation. One microgram of DNA was injected into the ventricle at embryonic day 15 (E15) on CD1 mouse embryos and electroporated (NEPA21 Super Electroporator, NEPAGENE; $30 \mathrm{~V}$; pulse ON, $50 \mathrm{~ms}$; pulse OFF, $950 \mathrm{~ms}$; 5 pulses) as described previously (Arango-Lievano et al., 2015). Mice were anesthetized with $4 \%$ isoflurane/oxygen and maintained at $1.5-2 \%$ isoflurane (Abbott Laboratories) throughout surgery using TEC3N (Anesteo). Mice received preemptive analgesia with lidocaine (Xylovet; $3.5 \mathrm{mg} / \mathrm{kg}$ at incision site). A subcutaneous injection of the analgesic buprenorphine (Buprecare; $0.05 \mathrm{mg} / \mathrm{kg}$ ) was administered postsurgery and the next day. The expression of transgenes in experimental animals generated by in utero electroporation was stable in adolescents but faded before reaching adulthood (ArangoLievano et al., 2016). Due to this technical reason, adolescent mice were used throughout the study.

Microdissection and lysate preparation. Animals were anesthetized with pentobarbital (for mice, $50 \mathrm{mg} / \mathrm{kg}$; for rats, $100 \mathrm{mg} / \mathrm{kg}$, i.p.; Ceva Santé Animale) before decapitation. Cortical biopsy samples were punched out of fresh mouse brain sections $(200 \mu \mathrm{m})$ on ice using a punch set and snap frozen in liquid nitrogen. Tissue homogenates were lysed in $10 \mathrm{~mm}$ Tris$\mathrm{HCl}, \mathrm{pH}$ 8.0, 150 mm NaCl, 1 mm EDTA, 10\% glycerol, 1\% NP-40, 0.1\% SDS, $0.1 \%$ Triton X-100 complemented with protease inhibitors, $1 \mathrm{~mm}$ $\mathrm{Na}_{3} \mathrm{VO}_{4}, 10 \mathrm{~mm} \mathrm{NaF}$, and $10 \mathrm{~nm}$ calyculin A. Protein samples for Western blot analysis were cleared from debris by centrifugation $(14,000 \mathrm{rpm}$ for $10 \mathrm{~min})$.

Cell culture and lysis. Time-pregnant Sprague Dawley rats (Janvier Labs) were killed by narcosis to prepare primary E18 cortical neurons cultured on glass coverslips coated with poly-D-lysine, and maintained in Neurobasal medium containing B27 supplement, $0.5 \mathrm{~mm}$ L-glutamine, 5-fluorouridine, and uridine (10 $\mu \mathrm{M}$ each; Thermo Fisher Scientific) as previously described (Lambert et al., 2013). HEK293 cells were grown in DMEM containing 10\% FBS. Cell lysates were prepared in $10 \mathrm{~mm}$ Tris$\mathrm{HCl}$, pH 8.0, 150 mм NaCl, 1 mм EDTA, 10\% glycerol, 1\% NP-40, 0.1\% SDS plus protease inhibitors, $1 \mathrm{~mm} \mathrm{Na}_{3} \mathrm{VO}_{4}, 10 \mathrm{~nm}$ calyculin $\mathrm{A}$, and 10 mM NaF and cleared (14,000 rpm for $10 \mathrm{~min})$. Primary cortical cultures were grown for 3 weeks (DIV21) before analysis of spine morphology and biochemistry.

DNA and transfections. Luciferase (Luc)-reporter constructs consist of a minimal POMC inactive promoter used as inactive control and $3 \times$ tandem NurRE-POMC fusion (a gift from J. Drouin, Montreal Clinical Research Institute, Montreal, QC, Canada). Short hairpin RNA (shRNA) plasmids against murin $n r 4 a 1$ and scramble (sc) sequences are from GeneCopoeia (Tebu-Bio). NR4A1 cDNA (a gift from P. Tontonoz, UCLA, Los Angeles, CA) was subcloned in pSLIK-venus under the control of a doxycycline-inducible promoter (ATCC). In vitro electroporation of plasmid constructs of primary cortical neurons were performed with the AMAXA System according to manufacturer instructions (Lonza). HEK293 cells were transfected with Lipofectamine 2000 (Thermo Fisher Scientific).

Mutagenesis. NR4A1 mutants [R337A, $\Delta$ NLS (nuclear localization sequence), S340A, and S350A] were made by site-directed mutagenesis using QuikChange (Agilent Technologies). Deletion mutant $\Delta \mathrm{AF} 1$ was generated by PCR and subcloned into pSLIK-venus. All constructs were verified by sequencing.

NR4A1 transcriptional activity. NurRE-Luc together with renilla plasmids (10:1 ratio) were electroporated in primary neurons or in layer II/III cortical neurons in vivo together with GFP (10:1:2 ratio). Luciferase/renilla activities were assessed with dual Luciferase reporter assay according to manufacturer instructions (Promega) from extracts of pri- mary neurons or GFP-positive biopsies of cortex microdissected under a fluorescence microscope (MZ16F Fluorescence Microscope, Leica Microsystems) from P31 mice anesthetized with pentobarbital $(50 \mathrm{mg} / \mathrm{kg}$, i.p.) and perfused at a rate of $3 \mathrm{ml} / \mathrm{min}$ through the ascending aorta with $30 \mathrm{ml}$ of ice-cold $0.9 \% \mathrm{NaCl}$ before decapitation.

Nuclear fractionation. To purify nuclear extracts, neurons were rinsed in ice-cold PBS and incubated for $15 \mathrm{~min}$ on ice with buffer A (10 mM HEPES-KOH, pH 7.9, 10 mm KCl, 0.1 mm EDTA, 0.1 mm EGTA, and 1 mм DTT with protease and phosphatase inhibitors) before harvesting, $0.5 \% \mathrm{NP}-40$ was added to the cells for $3 \mathrm{~min}$ on ice, and lysates were centrifuged for $1 \mathrm{~min}$ at $13,000 \mathrm{rpm}$. The resulting supernatant was stored as the cytoplasmic fraction, and the pellet was further rinsed in 1 $\mathrm{ml}$ of buffer $\mathrm{A}$. The pellet was vortexed for $20 \mathrm{~min}$ in $50 \mathrm{ml}$ of buffer B (20 mM HEPES- $\mathrm{NaOH}, \mathrm{pH}$ 7.9, $0.4 \mathrm{~mm} \mathrm{NaCl}, 1 \mathrm{~mm}$ EDTA, and 1 mm EGTA with protease and phosphatase inhibitors) and cleared by centrifugation for $10 \mathrm{~min}$ at 13,000 rpm. The resulting supernatant was collected as the nuclear fraction, and purity was assessed using markers HSP90 and HDAC2.

Immunoprecipitation. Protein concentrations were measured with the Bradford assay against BSA standards (Thermo Fisher Scientific). Polyclonal antibodies against pan-NR4A1 (E6, Santa Cruz Biotechnology) were used for immunoprecipitation with protein A-conjugated magnetic beads (Thermo Fisher Scientific) and Western blot for detecting Ubiquitin (P4D1, Cell Signaling Technology), cyto-NR4A1 (ABIN460855, antibodies-online.com) and pan-NR4A1 by chemiluminescence (ECL, GE Healthcare Life Sciences). Densitometric analysis of grayscale images was performed with ImageJ (NIH).

TMRM fluorescence live imaging. Imaging of TMRM $(50 \mu \mathrm{M})$, quenching mode (in $120 \mathrm{~mm} \mathrm{NaCl}, 3.5 \mathrm{~mm} \mathrm{KCl}, 0.4 \mathrm{~mm} \mathrm{KH}_{2} \mathrm{PO}_{4}, 15 \mathrm{~mm}$ glucose, $1.2 \mathrm{~mm} \mathrm{CaCl}_{2}, 5 \mathrm{~mm} \mathrm{NaHCO}_{3}, 1.2 \mathrm{~mm} \mathrm{Na}_{2} \mathrm{SO}_{4}$, and $20 \mathrm{~mm}$ HEPES, pH 7.4) with an inverted fluorescence microscope (model IX70, Olympus) coupled with a Coolsnap HQ Camera (Roper Scientific SARL) from primary cortical neurons electroporated with the indicated construct and seeded on poly-D-lysine-coated Ibidi glass bottom dishes (BioValley). GFP-positive cells were identified prior to recording changes of TMRM fluorescence over time $\left(\Delta F=F-F_{0} / F_{0} \times 100\right.$, where $F$ is fluorescence intensity at any time point and $F_{0}$ is baseline fluorescence) by illumination at $555 \mathrm{~nm}$ and detection at $570 \mathrm{~nm}$ (Metafluor software, Molecular Devices). Background intensity was subtracted from whole-cell intensity, and $F_{0}$ was measured as the average normalized fluorescence emitted during the $120 \mathrm{~s}$ before glutamate treatment. Images were captured every $5 \mathrm{~s}$. For quantification, we extracted the average of the last $3 \mathrm{~min}$ of each epoch (100 $\mu \mathrm{M}$ glutamate, washout, $1 \mu \mathrm{M}$ oligomycin, and $10 \mu \mathrm{M}$ FCCP) due to the lag of time during perfusion of drugs or a rinse with culture medium. Statistical comparisons between groups reported differences during epochs (glutamate: $N=16 \mathrm{GFP} ; N=27 \mathrm{NR} 4 \mathrm{~A} 1 ; N=7 \Delta \mathrm{AF} 1$; washout: $N=16 \mathrm{GFP} ; N=27 \mathrm{NR} 4 \mathrm{~A} 1 ; N=7 \Delta \mathrm{AF} 1$; oligomycin: $N=10$ GFP; $N=10$ NR4A1; $N=7 \Delta \mathrm{AF} 1 ; \mathrm{FCCP}: N=10 \mathrm{GFP} ; N=10 \mathrm{NR} 4 \mathrm{~A} 1$; $N=7 \Delta \mathrm{AF} 1)$.

ATP concentrations. Whole-cell ATP levels were monitored using the ATP Bioluminescence Assay Kit HSII according to manufacturer instructions (Sigma-Aldrich S.A.R.L.). ATP levels were normalized to the total amount of proteins dosed with Bradford assay against BSA standards (Thermo Fisher Scientific).

Golgi staining and dendritic spine studies. Animals were anesthetized with pentobarbital $(50 \mathrm{mg} / \mathrm{kg}$, i.p.) and perfused at a rate of $3 \mathrm{ml} / \mathrm{min}$ through the ascending aorta with $30 \mathrm{ml}$ of $0.9 \% \mathrm{NaCl}$ prior decapitation. The FD-Rapid GolgiStain Kit was used according to manufacturer instructions (FD Neurotechnologies), and labeled brain slices were imaged with transmitted light on an AxioImager Z1 (Carl Zeiss) equipped with a $100 \times$ oil-immersion objective. Fluorescence images from blinded groups were taken on an LSM510 laser-scanning confocal microscope (pinhole set to 1 airy unit; Carl Zeiss) equipped with $63 \times$ Plan-Neofluor NA1.3 oil-immersion objective and digital zoom 8 . Z-stack images were processed using ImageJ (NIH). Laser excitation, fluorescence emission capture, and the pinhole were held constant throughout the study. Dendritic segments included in the analysis met the following criteria: (1) segments must be parallel or at acute angles relative to the coronal surface of sections to allow unambiguous identification of spines; (2) seg- 
A

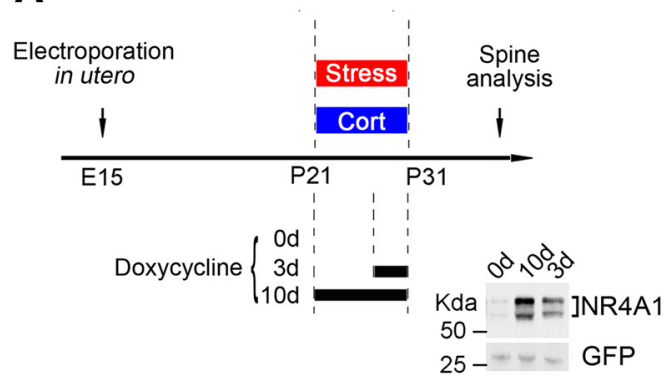

C

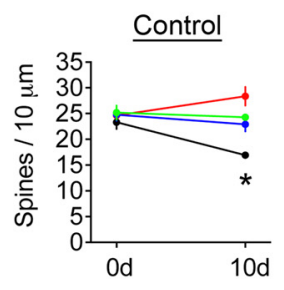

E

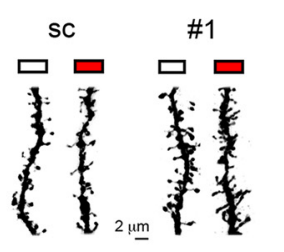

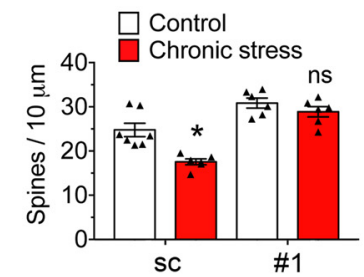
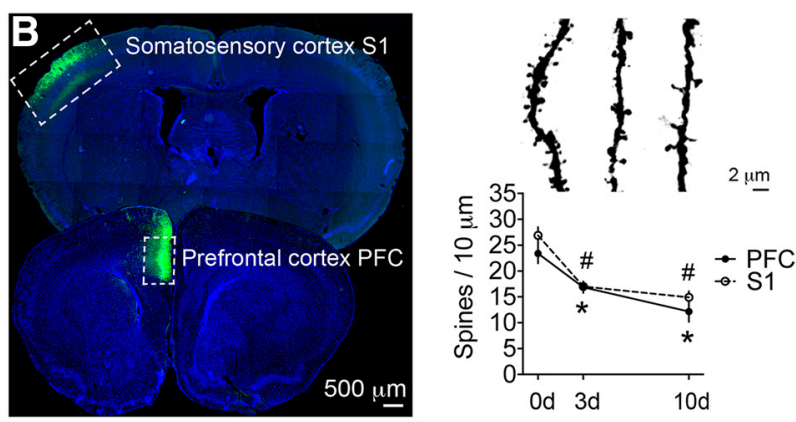

D

\section{NR4A1 knockdown shRNA}

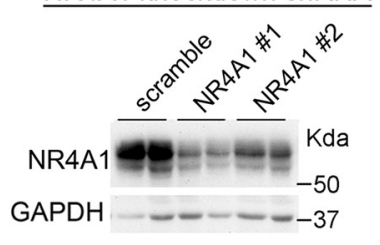

$\mathbf{F}$

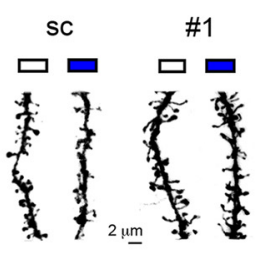

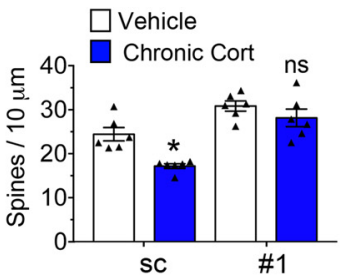

Figure 1. Chronic activation of the glucocorticoid stress pathway required NR4A1 for dendritic spine attrition in pyramidal neurons of mouse cortex. A, Experimental timeline: doxycyclineinducible NR4A1 construct (with GFP reporter) was electroporated in utero, and doxycycline was administered in drinking water for the indicated days between P21 and P31. During this period, mice were exposed either to daily unpredictable stress or CORT injections (15 mg/kg). See extended data Figure 1-1 available at https://10.1523/JNEUROSCI.2793-17.2017.f1-1. B, Spine density at apical tuft dendrites of cortical pyramidal L2/3 neurons of S1 and PFC electroporated with NR4A1 (mean \pm SEM of $N=5$ mice/group, ANOVA post hoc Bonferroni's test comparing 0 vs $3 \mathrm{~d}$ : \#p $=0.0168$; ${ }^{*} p<0.0001 ; 0$ vs $10 \mathrm{~d}:{ }^{*}, \# p<0.0001$ ). See extended data Figure 1-2 available at https://10.1523/JNEUROSCI.2793-17.2017.f1-2. C, Spine density at apical tuft dendrites of cortical pyramidal L2/3 neurons electroporated with NR4A1 constructs in S1. Mice were either reared in standard homecage conditions or exposed to chronic unpredictable stress. Mean \pm SEM of $N=5-7$ mice/group; ANOVA post hoc Bonferroni's test: NR4A1 vs GFP, ${ }^{*} p=0.0031$; stress vs controls; $\# p=0.0015$; interaction of stress and DNA construct expression post hoc Bonferroni's test $\Delta$ AF1, op $=0.0018$. $D$, Knockdown of transfected NR4A 1 in HEK cells with shRNA\#1 and \#2 compared with sc sequence. $E$, Effect of NR4A1 knockdown on stress-induced spine loss at apical tuft dendrites of pyramidal L2/3 neurons in $\mathrm{S} 1$ (mean \pm SEM of $N=6$ mice/group; ANOVA post hoc Bonferroni's test comparing stress and controls in scramble group, ${ }^{*} p=0.0018$ ). See extended data Figure 1-3 available at https://10.1523/JNEUROSCI.2793-17.2017.f1-3. F, Effect of NR4A1 knockdown on CORT-induced spine loss at apical tuft dendrites of pyramidal L2/3 neurons in S1 (mean \pm SEM of $N=6-7$ mice/group; ANOVA post hoc Bonferroni's test comparing stress and controls in scramble group, ${ }^{*} p=0.0017$ ). See extended data Figure $1-3$ available at https://10.1523/JNEUROSCI.2793-17.2017.f1-3.

ments had no overlap with other branches; (3) dendritic segments from apical tuft were imaged in cortical layer 1 distant from $\sim 100 \mu \mathrm{m}$ from pyramidal neuronal soma in layer 2; and (4) dendritic segments from apical tuft were imaged in cortical layer 1 at a distance of $\sim 200 \mu \mathrm{m}$ from pyramidal neuronal soma in layer 3 . The total length of dendrites analyzed for dendritic spine density exceeded $100 \mu \mathrm{m} /$ mouse, which exceed $500 \mu \mathrm{m} /$ group, depending on the number of animals. Not more than two dendritic segments per cell (for which branch order was not recorded) were scored in a total of 10-15 cells/per group. Thin, mushroom, and stubby spines were counted as one unique category, and filopodia were disregarded because they were extremely rare at P31. A total exceeding 1000 dendritic spines from at least 20-30 dendritic segments were counted per group, which depended on the number of animals per group ( $N$ is indicated in the figure legends). The number of dendritic spines enumerated at pyramidal cortical neurons depends on methodology, species, and age, as previously reported (Cerqueira et al., 2007; Radley et al., 2008; Bloss et al., 2011; Anderson et al., 2016). For example, the range is 15-30 spines $/ 10 \mu \mathrm{m}$ at apical tuft dendrites of PFC in adolescent mice monitored by fluorescence confocal microscopy in Figure 1 and as described previously (Radley et al., 2008; Swanson et al., 2013), whereas it is 6-13 spines $/ 10 \mu \mathrm{m}$ at apical tuft dendrites of PFC in adolescent mice monitored in Golgi-Cox-impregnated neurons imaged by transmitted light microscopy in Figure 2 and as described previously (Cerqueira et al., 2007). In vitro after 3 weeks in culture, the range is three to seven dendritic spines per $10 \mu \mathrm{m}$ in primary cortical neurons in Figure $6 \mathrm{~F}$ and as described previously (Arango-Lievano et al., 2015).

Histochemistry. Animals were anesthetized with pentobarbital $(50 \mathrm{mg} /$ kg, i.p.) and perfused at a rate of $3 \mathrm{ml} / \mathrm{min}$ through the ascending aorta with $30 \mathrm{ml}$ of $0.9 \% \mathrm{NaCl}$, followed by $30 \mathrm{ml}$ of $4 \%$ ice-cold PFA. Brains were harvested and postfixed for $2 \mathrm{~h}$ and equilibrated in 30\% sucrose (Sigma-Aldrich S.A.R.L.). Free-floating coronal sections rinsed in PBS were blocked in 5\% normal goat serum, 5\% normal horse serum, PBS, and $0.1 \%$ Triton $\mathrm{X}-100$ for $2 \mathrm{~h}$ at $25^{\circ} \mathrm{C}$. Primary antibodies (GFP, 1:3000; RFP, 1:2000; pan-NR4A1, 1:400) were incubated for $2 \mathrm{~d}$ at $4^{\circ} \mathrm{C}$, and secondary antibodies (1:2000; Thermo Fisher Scientific) for $2 \mathrm{~h}$ at $25^{\circ} \mathrm{C}$. Cultured cells were fixed in 4\% PFA, 20\% sucrose in PBS for 10 min at $25^{\circ} \mathrm{C}$. After quenching the fixative with $50 \mathrm{~mm} \mathrm{NH}_{4} \mathrm{Cl}$ in PBS, cells were permeabilized with $0.1 \%$ Triton X-100 in PBS for 3 min; blocked with $10 \%$ goat serum, $2 \% \mathrm{BSA}$, and $0.25 \%$ fish skin gelatin in TBS for $30 \mathrm{~min}$; and then incubated with antibodies for $3 \mathrm{~h}$ in blocking solution at room temperature. Cells were washed in TBS, $0.25 \%$ fish skin gelatin, and mounted in mowiol (Sigma-Aldrich S.A.R.L.). Antibodies against p-NR4A1 and cyto-NR4A1 did not work for immunostaining. This is why quantitative analyses were performed by Western blot. NR4A1 antibodies rec- 
A
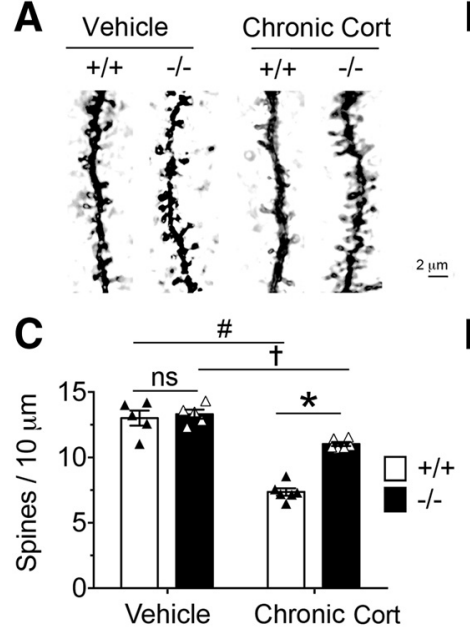

B

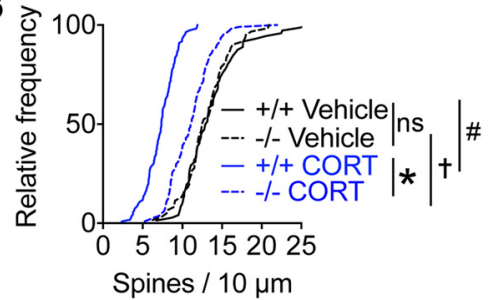

D

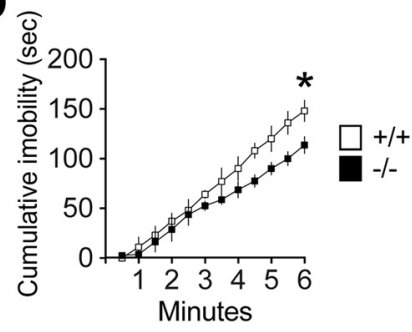

Figure 2. Knockout of NR4A1 protected against adverse effects of chronic CORT injections. $A$, Apical tuft dendrites of Golgiimpregnated pyramidal L2/3 neurons in PFC from NR4A1 K0 mice exposed to vehicle or CORT daily injections between P21 and P31. $B$, Distribution of dendritic spine territories at the apical tuft of the layer $2 / 3$ neurons in PFC (dendrites for vehicle groups: $N=72$ $+/+; N=61-/-;$ dendrites for CORT groups: $N=110+/+; N=107-/-$ ). Comparison with K-S test: ${ }^{*}, \# p<0.0001$; $t p=0.0016$. C, Group effects on spine density (mean \pm SEM of $N=5-6$ mice/group; ANOVA post hoc Bonferroni's test comparing the effect of genotype and CORT treatment: $\left.{ }^{*}, \# p<0.0001 ; \uparrow p=0.0066\right)$. $D$, Immobility time in the TST of CORTinjected NR4A1 K0 mice compared with wild-type littermates (mean \pm SEM of $N=5-6$ mice/group;ANOVA post hoc Sidak's $t$ test comparing total immobility time between genotypes, $\left.{ }^{*} p<0.05\right)$.

ognized two major bands at 60 and $75 \mathrm{kDa}$, which disappear in $\mathrm{KO}$ cultures (Chen et al., 2014). Post-translational modifications like phosphorylation, ubiquitination, and sumoylation explain, in part, the shift of molecular weights (Hazel et al., 1991; Chen et al., 2014; Zhang et al., 2017).

RNA extraction. Total RNA from primary neurons was extracted with TRIzol (Thermo Fisher Scientific), and cDNA was synthesized from $1 \mu \mathrm{g}$ of RNA using the First-Strand cDNA Synthesis Kit for Real-Time PCR (USB, Thermo Fisher Scientific) and random primer mix (USB, Thermo Fisher Scientific).

Quantitative PCR. The Hot-start SYBR Green PCR kit (Qiagen) was used in $10 \mu \mathrm{l}$ reactions containing $2.5 \mu \mathrm{l}$ of cDNA and a $100 \mathrm{~nm}$ primer mixture. The rodent-specific primers used are as follows: $d r p 1,5^{\prime}$-TGAT GGGAAGGGTTATTCCA-3' and 5'-TGGCCAGAGATGGGTACTTC-3'; $m f n 1,5^{\prime}$-TCGCAGTCAGCAGTGAAAAC-3' and 5' -TGCCACGTTTAC TGAGTCCA- $3^{\prime}$; $m f n 2,5^{\prime}$-AGGAAATTGCTGCCATGAAC- $3^{\prime}$ and $5^{\prime}-$ TGTTGAGTTCGCTGTCCAAC-3'; opal, 5'-GGACCCAAGAGCAGT GTGTT-3' and 5' -GGTTCTTCCGGACTGTGGTA-3' ; fis 1, 5' -GCCTGG TTCGAAGCAAATAC-3' and 5'-CACGGCCAGGTAGAAGACAT-3'; ucp2, 5' -ACAAGACCATTGCACGAGAG-3' and 5' -ATGAGGTTGGCT TTCAGGAG-3'; ucp4, 5'-TCTCACAAAAACCCGACTCC-3' and 5'ACCATCCGACCTCCAGAGTA-3'; $u c p 5,5^{\prime}$-GGAATGCTGGGAGAC ACAAT-3' and 5'-GTCCCACTATTGCCCTCTGA-3'; gapdh, 5' -cctgca ccaccaactgcttag- $3^{\prime}$ and $5^{\prime}$-ctgtggtcatgagcccttcc- $3^{\prime}$; human $n r 4 a 1.3,5^{\prime}$-tct atgtcctcgccttggtt- $3^{\prime}$ and $5^{\prime}$-attatccotctgccttcag- $3^{\prime}$; and human $t u b b, 5^{\prime}$ cagggcttccagctgacccactc- $3^{\prime}$ and $5^{\prime}$-gtgagggcatgacgctgaaggtg- $3^{\prime}$. Quantitative PCR (qPCR) was performed with an ABI 7900 Instrument (Thermo Fisher Scientific), followed by melt-curve analysis. Fold changes in gene expression were calculated using the $\Delta \Delta \mathrm{Ct}(\mathrm{Ct}=$ cycle number at threshold) analytical method, which includes normalization against housekeeping gene human TUBB (encoding $\alpha$-tubulin) or rodent GAPDH.

Human studies: $A D$. Frozen tissues corresponding to Brodmann areas 9-10 (medial anterior prefrontal cortex) from 24 case patients in whom $\mathrm{AD}$ was diagnosed (12 with moderate AD: 7 females/5 males; 12 with severe AD: 8 females/ 4 males) and 17 healthy cognitively normal control subjects ( 6 females/11 males) were obtained from the Rush Memory and Aging Project and Religious Orders Study, the University of Pennsylvania Brain Bank (Center for Neurodegenerative Disease Research, Philadelphia, PA), the Harvard Brain Bank (Harvard Brain Tissue Resource Center, Belmont, MA), and the Emory Brain Bank (Center for Neurode- generative Disease, Atlanta, GA) as previously described (Ginsberg et al., 2010a,b; ArangoLievano et al., 2016) with a premortem clinical diagnosis and cognitive assessment scores collected within 1 year before death using the Mini-Mental State Examination (MMSE; Folstein et al., 1975). A board-certified neuropathologist blinded to the clinical diagnosis performed a neuropathological diagnosis based on established criteria (Braak and Braak, 1991; Hyman and Trojanowski, 1997). Exclusion criteria included argyrophilic grain disease, frontotemporal dementia, Lewy body disease, mixed dementias, Parkinson's disease, and stroke. Subject groups matched as closely as possible for age and postmortem interval (PMI; for details, see Fig. 9-1 available at https://10.1523/JNEUROSCI.2793-17.2017.

f9-1). Medications for persons during life were not accessible as per Health Insurance Portability and Accountability Act of 1996 (HIPAA) guidelines for a pathological study. Informed consent was obtained for all subjects. This study is performed under the guidelines of the Nathan S. Kline Institute and the NYU Langone Medical Center. Tissue samples were processed as described previously (Ginsberg et al., 2000; Counts et al., 2004), and Western blots repeated five times for each sample to ascertain reproducibility and minimize experimental bias. Experimentalists were blind to the groups. Digitized data were measured by optical densitometric analysis with NIH ImageJ, and background was subtracted and normalized to GAPDH levels.

Human studies: MDD. Frozen tissues corresponding to Brodmann area 9 (medial prefrontal cortex) from 27 depressed subjects ( $14 \mathrm{fe}$ males/13 males) and 27 psychiatrically healthy control subjects ( $14 \mathrm{fe}$ males/13 males) matched for sex and as closely as possible for age and PMI were obtained from the University of Pittsburgh Brain Tissue Donation Program (Pittsburgh, PA). All tissue samples were obtained at autopsy following consent from the next of kin. All depressed subjects met the diagnostic criteria for MDD according to the Diagnostic and Statistical Manual of Mental Disorders, fourth edition (American Psychiatric Association, 1994). Control subjects did not meet the criteria for an axis I disorder at any time in their lives. Subject groups did not differ in mean age, PMI, brain pH, RNA integrity number, or tissue storage time (for details, see Fig. 8-1 available at https://10.1523/JNEUROSCI. 2793-17.2017.f8-1). Informed consent was obtained for all subjects. Details of medications of persons during life were not accessible as per HIPAA guidelines for a pathological study. This study is performed under the guidelines of the Yale University School of Medicine. Total RNA (500 ng) extracted from human PFC was reverse transcribed into cDNA using random hexamer primer mix and SuperScriptIII qRT-PCR Kit (Thermo Fisher Scientific; Duric et al., 2010). Experimentalists were blinded to the subject groups. A combination of factors accounted for the reduced number of samples $(N=25$ control subjects and $N=24$ MDDs $)$ in the qPCR analysis (e.g., low signal strength or statistical outliers based on SD).

Statistics. Data were compared using a two-tailed Student's $t$ test, correlated with Pearson $r$ for comparing two sets of variables. Cumulative distribution comparing two variables was performed with KolomogorovSmirnov (K-S) test. We used a factorial ANOVA to compare multiple groups, using stress status, CORT treatment, genotypes, NR4A1 constructs, doxycycline treatment serving as independent factors, followed by post hoc pairwise comparison with appropriate tests (Sidak's, Dunnett's, and Bonferroni's tests) conducted with Prism version 6.0 (GraphPad Software). All data are shown as the mean \pm SEM. Statistical significance was set at $p<0.05$. Statistical outliers twofold higher than SD were removed from analysis of $N r 4 a 1$ mRNA in an MDD cohort. No data from animal studies were removed from analyses. For in vivo exper- 
iments, the number of dendritic spines was averaged per animal and per group (e.g., one to two dendritic segments/neuron, five to seven neurons/mouse; $N=5-7$ mice as per group conditions). For in vitro experiments, the number of culture dishes per group was equivalent to the number of independent experiments. Estimates of sample size were calculated by power analysis based on preliminary data. Sample size was chosen to ensure $80 \%$ power to detect the prespecified effect size. Animals and culture dishes were attributed to various experimental groups in a random fashion. All data collected in animals were from littermate controls and were averaged per experimental groups. Knock-out animals were bred as heterozygotes to generate homozygote littermates. All data collected in vitro were replicates from independent experiments and averaged per experimental groups. Pre-established criteria for stopping data collection included the following: (1) mice electroporated in the wrong cortical regions; (2) mice reaching ethical end point limits; (3) unexpected mortality (e.g., one mouse NR4A1 KO injected with CORT died); and (4) brains badly perfused and unusable for histological studies.

\section{Results}

\section{NR4A1 caused dendritic spine attrition in vivo via a genomic mechanism}

To test whether NR4A1 regulates dendritic spine number postdevelopment in vivo when it is most expressed (Fig. 1-1 available at https://10.1523/JNEUROSCI.2793-17.2017.f1-1; Chan et al., 1993; Davis and Puhl, 2011), we used a doxycycline-inducible construct to achieve temporal control of NR4A1 expression between P21 and P31 (Fig. 1A). Analysis of the apical tuft dendrites in NR4A1-overexpressing pyramidal neurons in PFC and S1 at P31 indicated that spine number was reduced upon exposure to doxycycline (two-way ANOVA for effect of doxycycline: $F_{(2,24)}=$ 31.12, $p<0.0001$, post hoc Bonferroni's test comparing $0 \mathrm{~d}$ with $3 \mathrm{~d}, p=0.0168$; and comparing $0 \mathrm{~d}$ with $10 \mathrm{~d}, p<0.0001$; Fig. $1 B)$. This was not an artifact of doxycycline given that neurons expressing GFP alone maintained similar spine density in the presence or absence of treatment (unpaired $t$ test, $t_{(9)}=0.66, p=$ 0.52; Fig. $1 C$ ). These spines contain PSD-95 puncta juxtaposed with synaptophysin puncta suggestive of functional connectivity (Fig. 1-2 available at https://10.1523/JNEUROSCI.2793-17.2017. f1-2).

To determine whether NR4A1 used a genomic mechanism to reduce dendritic spine number in vivo, we electroporated doxycycline-inducible NR4A1 mutants: (1) $\Delta$ AF1 lacks the transactivation domain (Calnan et al., 1995); and (2) R337A cannot bind to DNA (Meinke and Sigler, 1999). Both mutants induced from P21 to P31 failed to diminish dendritic spine coverage in pyramidal neurons contrary to the wild-type (WT; main effect of NR4A1 constructs by two-way ANOVA: $F_{(3,36)}=9.82, p<$ 0.0001 ; effect of interaction of doxycycline with NR4A1 constructs: $F_{(3,36)}=5.95, p=0.0021$; post hoc Bonferroni's test for the effect of WT, $p=0.0031 ; \Delta \mathrm{AF} 1, p=0.12$; and R337A, $p=$ 0.97; Fig. $1 C$ ). These data indicated that NR4A1 required its transactivation domain for dendritic spine attrition in vivo.

\section{Stress- and CORT-mediated dendritic spine loss in cortex required NR4A1}

NR4A1 expression in the adult brain is very sensitive to stress and CORT (Helbling et al., 2014), implying that it could contribute to dendritic spines attrition in such contexts. To address this possibility, we used $\Delta \mathrm{AF} 1$ as a dominant-negative approach to block dendritic spine loss caused by chronic unpredictable and uncontrollable stress (main effect of stress compared with controls: two-way ANOVA, $F_{(1,19)}=39.89$, $p<0.0001$; post hoc Bonferroni's test, $p=0.0015$; Fig. $1 C$ ). Induction of $\Delta \mathrm{AF} 1$ in mouse cortex with doxycycline supplied during the entire stress paradigm from P21 to P31 preserved dendritic spines compared with induction of GFP (main effect of $\triangle \mathrm{AF} 1$ by two-way ANOVA: $F_{(1,22)}=7.1$, $p=0.0014$; interaction of doxycycline with $\Delta \mathrm{AF} 1: F_{(1,22)}=9.426$, $p=0.0056$; post hoc Bonferroni's test for the effect of $\Delta \mathrm{AF} 1: p=$ 0.0018; and GFP: $p>0.99$; Fig. $1 C$ ). To confirm this result, we aimed at silencing the endogenous NR4A1 expression with shRNA sequences that are efficient at downregulating recombinant NR4A1 in vitro (Fig. 1D). The most efficient short hairpin (sh) sequence, sh\#1, was introduced in cortex by in utero electroporation during embryogenesis and compared with its scrambled (sc) sequence as a control. Sh\#1 prevented stress-induced spine loss (main effect of sh\#1 by two-way ANOVA: $F_{(1,21)}=52.3, p<$ 0.0001 ; main effect of stress: $F_{(1,21)}=14.53, p=0.001$; interaction of sh\#1 with stress: $F_{(1,21)}=4.72, p=0.04$; post hoc Bonferroni's test on scramble group: $p=0.0018$; and post hoc Bonferroni's test on sh\#1 group: $p>0.99$; Fig. $1 E$ ), uniformly at the apical tuft dendrites (Fig. 1-3A available at https://10.1523/ JNEUROSCI.2793-17.2017.f1-3). Sh\#1 also prevented CORTmediated spine loss (main effect of sh\#1 by two-way ANOVA: $F_{(1,21)}=36.02, p<0.0001$; main effect of CORT: $F_{(1,21)}=$ $13.15, p=0.0016$; interaction of sh\#1 and CORT: $F_{(1,21)}=2.3$; post hoc Bonferroni's test effect on scramble group: $p=0.0017$; and post hoc Bonferroni's test effect on sh\#1 group: $p=0.4$; Fig. $1 F$ ), uniformly at the apical tuft dendrites (Fig. 1-3B available at https://10.1523/JNEUROSCI.2793-17.2017.f1-3). These results indicate that dendritic spine plasticity to stress and CORT depended on NR4A1 expression.

\section{Knockout of NR4A1 protected against adverse effects of chronic CORT exposure}

We sought confirmation in NR4A1 knock-out mice using the chronic CORT exposure model. Morphological analysis of GolgiCox-impregnated pyramidal neurons (Fig. $2 A$ ) showed that the distribution of dendritic spines (Fig. $2 B$ ) and the overall density in PFC was denser in $-/-$ than in $+/+$ mice after chronic CORT exposure (main effect of genotype by two-way ANOVA: $F_{(1,16)}=$ 26.37, $p<0.0001$; main effect of CORT: $F_{(1,16)}=105.6, p<$ 0.0001 ; interaction of genotype and CORT: $F_{(1,16)}=19.2, p=$ 0.0005; post hoc Bonferroni's test: $p<0.0001$; and effect of CORT injection: $F_{(1,16)}=105.6$; post hoc Bonferroni's test: $p<0.0001$; Fig. 2C). Another typical adverse effect of chronic CORT exposure is behavioral despair in the TST (Nestler and Hyman, 2010) in which $-/-$ mice performed better than $+/+$ mice (main effect of genotype by two-way ANOVA: $F_{(1,91)}=26.34, p<0.0001$; post hoc Sidak's $t$ test comparing total time immobile between genotypes: $p<0.05$; Fig. $2 B$ ). These data indicated that the knockout of NR4A1 protected against some adverse effects of chronic CORT exposure.

\section{Chronic stress and CORT exposure increased NR4A1 activity in mouse cortex}

Knockdown, knockout, and dominant-negative data all suggested that NR4A1 could be more active upon stimulation of the glucocorticoid stress pathway than at rest. To monitor NR4A1 activity in pyramidal neurons of PFC, we established a transcription-based Luciferase assay in vivo. A synthetic promoter harboring $3 \times$ tandem NR4A1-reponsive elements (NurREs) upstream of Luciferase showed endogenous activity in mouse cortex at rest at P31 compared with cortical tissue electroporated with the minimal promoter lacking NurRE (unpaired $t$ test: $t_{(8)}=5.63, p=0.0005$; Fig. $3 A$ ). Using this assay, we found that chronic CORT exposure and stress increased the activity of neuronal NR4A1 in mouse cortex 

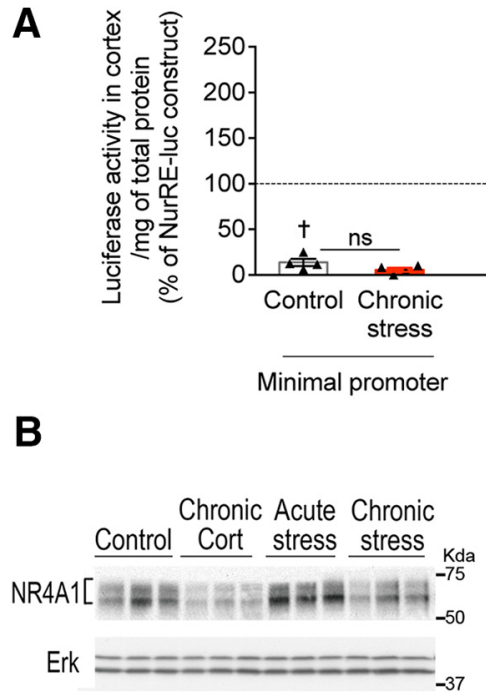

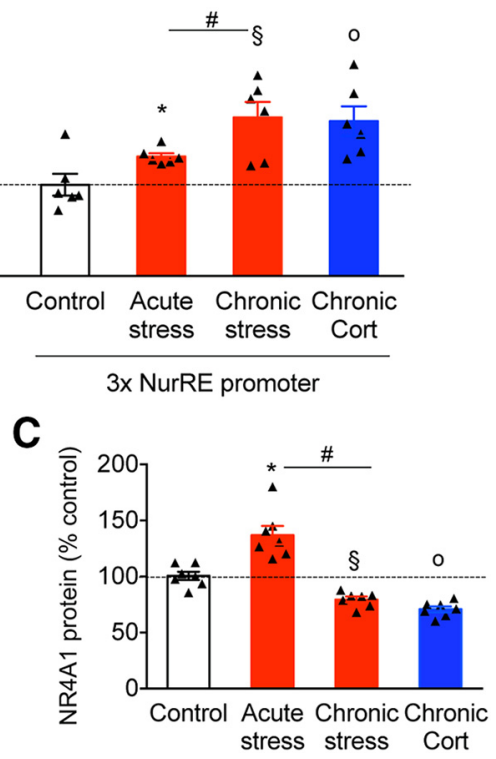

Figure 3. Chronic activation of the glucocorticoid stress pathway increased NR4A1 transcriptional activity in pyramidal L2/3 neurons of mouse PFC. $A$, Luciferase activity at NR4A1 reporter NurRE-Luc compared with a minimal reporter construct introduced with a GFP reporter in cortical L2/3 neurons by electroporation in utero. Luc activity monitored at P31 ex vivo after microdissection of GFP-labeled PFC tissue. Data normalized to total milligrams of protein of GFP dissected tissues are expressed as a percentage of the NurRE-Luc construct in control resting mice (mean $\pm \mathrm{SEM}$ of $N=4$ mice with minimal promoter/group; $N=6$ mice with NurRE/group, unpaired $t$ test; $\nmid p=0.0005,{ }^{*} p=0.033,0 p=0.006, \S p=0.005$ compared with controls; $\# p=0.033$ comparing acute and chronic stress). $\boldsymbol{B}$, Western blots of PFC lysates from P31 mice subjected to acute stress, chronic stress, or CORT injections compared with controls. C, Protein levels of NR4A1 (mean \pm SEM of $N=7$ mice/group) expressed as a percentage of controls. Unpaired $t$ test: ${ }^{*} p=0.0016, o p<0.0001, \S p<0.0001$ comparing indicated treatment to controls; $\# p<0.0001$ comparing acute and chronic stress.

compared with controls at rest (acute stress: unpaired $t$ test, $t_{(10)}=$ $2.46, p=0.033$; chronic stress: unpaired $t$ test, $t_{(10)}=3.53, p=0.005$; and chronic CORT administration: unpaired $t$ test, $t_{(10)}=3.46, p=$ 0.006). Remarkably, chronic stress had a stronger effect than acute stress on activating NR4A1 in PFC (unpaired $t$ test: $t_{(10)}=2.45, p=$ $0.033)$.

To confirm this result, we used Western blot to detect NR4A1 total protein levels in PFC lysates (Fig. $3 B, C$ ). Acute stress increased NR4A1 levels compared with controls (unpaired $t$ test: $\left.t_{(12)}=4.06, p=0.0016\right)$, whereas chronic stress decreased NR4A1 levels compared with controls (unpaired $t$ test: $t_{(12)}=$ $4.72, p=0.005)$. We found the same comparing chronic CORT to control groups (unpaired $t$ test: $t_{(12)}=6.65, p<0.001$ ). The difference between acute and chronic stress was significant (unpaired $t$ test: $t_{(12)}=6.72, p<0.0001$; Fig. $3 C$ ), featuring a possible sensitization phenomenon. One issue raised by these data is the discrepancy between NR4A1 activity and NR4A1 levels in the context of chronic stress and CORT exposure.

\section{Transcriptional activity of neuronal NR4A1 depended on its} nuclear localization, phosphorylation, and turnover

We explored the possibility that the activity of neuronal NR4A1 could depend on nuclear export besides its levels. For this, we used BDNF as a tool in an in vitro system to force NR4A1 nuclear export in cortical neurons because TrkB is abundant in pyramidal cortical neurons (Jeanneteau et al., 2008), NR4A1 nuclear export was achieved in PC12 cells with a related neurotrophin (Katagiri et al., 2000), and BDNF expression is decreased by chronic stress and chronic CORT exposure (Duman, 2004; Arango-Lievano et al., 2015), which is relevant to the neuropathology of stressrelated disorders (Autry and Monteggia, 2012). As anticipated, BDNF suppressed the transcriptional activity of NR4A1 in pri- mary cortical neurons (unpaired $t$ test: $t_{(6)}$ $=2.57, p=0.042$; Fig. $4 A$ ). Subcellular fractionation to separate nuclear proteins from the cytosol indicated that NR4A1 was mostly nuclear in untreated neurons and mostly cytosolic after BDNF treatment (Fig. 4B). Furthermore, we characterized the following three antibodies to distinguish between the cytosolic and nuclear isoforms of NR4A1 (Fig. 4B): (1) the antibody against the phosphorylated residue Ser350 (p-NR4A1); (2) the antibody raised against the epitope-containing residues 325-374 (cyto-NR4A1); and (3) the antibody against both nuclear and cytosolic isoforms for total protein levels (pan-NR4A1).

To demonstrate the link among NR4A1 transcriptional activity, phosphorylation, and nuclear export, we used NR4A1 mutants. Deletion of the phosphorylation site (S350A), the $\Delta$ NLSs, the DNA-binding motif (R337A), or the transactivation domain $(\Delta \mathrm{AF} 1)$, all impaired NR4A1 nucleo-cytoplasmic ratio and transcriptional activity in primary cortical neurons (main effect of mutants by ANOVA: $F_{(3,8)}=$ $28, p=0.0001$; post hoc Dunnett's test for comparing $\Delta$ NLS and WT: $p=0.0001$; post hoc Dunnett's test for comparing R337A and WT: $p=0.0002$; post hoc Dunnett's test for comparing $\triangle \mathrm{AF} 1$ and WT: $p=0.0004$; Fig. 4C,D). Additionally, NR4A1 ubiquitination was higher at the cytosolic isoform than the nuclear isoform (Fig. 4E), and NR4A1 downregulation was higher at the cytosolic isoform than the nuclear isoform (main effect of BDNF by two-way ANOVA: $F_{(1,6)}=38.24, p=0.0008$; interaction of BDNF with time: $F_{(4,24)}=12.18, p<0.0001$; post hoc Sidak's test for comparing BDNF and vehicle: at 2, 4 , and $6 \mathrm{~h}, p<0.0001$; at $8 \mathrm{~h}, p=$ 0.0002; Fig. $4 F$ ). Altogether, these data indicated that cytosolic NR4A1 was not transcriptionally active and most likely was degraded.

\section{Stress and CORT altered the nuclear localization, phosphorylation, and levels of NR4A1}

To determine NR4A1 subcellular localization in vivo, we used the antibodies characterized in vitro. The pan-NR4A1 antibody detected total levels in both nucleus and cytosol of pyramidal neurons (labeled with thy1-YFP) in mouse PFC at rest (Fig. 5A). The nucleus/cytosol ratio of pan-NR4A1 increased by acute stress (unpaired $t$ test: $t_{(18)}=7.53, p<0.0001$ ), chronic stress (unpaired $t$ test: $\left.t_{(17)}=12.2, p<0.0001\right)$ and chronic CORT exposure (unpaired $t$ test: $t_{(15)}=14.1, p<0.0001$ ). We used Western blot to quantify p-NR4A1 and cyto-NR4A1 in PFC lysates, as the antibodies did not work for histology (Fig. 5B). Acute stress increased p-NR4A1 compared with controls (unpaired $t$ test: $t_{(22)}=$ 2.69, $p=0.013$; Fig. $5 C$ ) and also increased cyto-NR4A1 compared with controls (unpaired $t$ test: $t_{(12)}=2.55, p=0.025$; Fig. $5 D)$. In contrast, we found the opposite comparing chronic stress to controls [effect on p-NR4A1: unpaired $t$ test, $t_{(16)}=2.74, p=$ 0.014 (Fig. $5 C$ ); effect on cyto-NR4A1 levels: unpaired $t$ test: $t_{(11)}=$ $4.48, p=0.0009$ (Fig. 5D)] and chronic CORT exposure to controls [effect on p-NR4A1: unpaired $t$ test, $t_{(16)}=2.95, p<0.009$ (Fig. $5 C$ ); effect on cyto-NR4A1 levels: unpaired $t$ test, $t_{(12)}=$ 
7.53, $p<0.0001$ (Fig. 5D)]. This was not a generalized effect on proteins sensitive to stress and CORT exposure because FKBP51 was induced in these contexts (Fig. 5B).

Again, different effects between acute and chronic stress on pan-NR4A1 nucleus/cytosol ratio (unpaired $t$ test: $t_{(17)}=$ $4.18, p=0.0006$; Fig. 5A), p-NR4A1 (unpaired $t$ test: $t_{(16)}=2.71, p=0.015$; Fig. $5 C)$ and cyto-NR4A1 (unpaired $t$ test: $t_{(11)}=3.9, p=0.0025$; Fig. $5 D$ ), featured a putative sensitization phenomenon. Based on in vitro and in vivo data, we proposed a hypothetical model (Fig. 5E) in which stress signals could influence transcriptional activity of neuronal NR4A1 by phosphorylation, nuclear export, and degradation by the ubiquitin-proteasome system.

Genes regulated by neuronal NR4A1 are involved in mitochondrial uncoupling

NR4A1 activity regulates the expression of genes involved in cellular metabolism and cytoskeleton structure (Chao et al., 2007; Fassett et al., 2012; Chen et al., 2014). Here, we examined the expression of mitochondria-regulatory genes because both neuronal mitochondria and neuronal excitability were influenced by NR4A1 in a seizure model (Zhang et al., 2009). Compared with GFP, NR4A1 modified the expression of uncoupling proteins (Ucp2: unpaired $t$ test, $t_{(6)}=5.1, p=$ 0.002; Ucp4: unpaired $t$ test, $t_{(6)}=2.18$, $p=0.035$; Table 1), an effect blocked by BDNF as it caused NR4A1 nuclear export in cortical neurons. We used glutamate rather than CORT to simulate the effects of chronic stress in vitro because inhibitors of glutamate receptors blocked the effects of CORT and chronic stress on dendritic spine plasticity and neurotransmission (Duman, 2004; Popoli et al., 2011). We found that NR4A1 regulated more genes in the context of glutamate stimulation, as follows: Ucp4 (unpaired $t$ test: $t_{(6)}=4.94, p=0.0026$ ); Mfn1 (unpaired $t$ test: $\left.t_{(6)}=2.03, p=0.044\right)$; Fis1 (unpaired $t$ test: $t_{(6)}=3.48, p=0.013$ ); and Opal (unpaired $t$ test: $t_{(6)}=2.3, p=$ 0.033 ), unraveling a context-dependent effect. The consistent upregulation of $U c p 4$ mRNA at rest and after glutamate stimulation suggested that NR4A1 could affect ATP stocks by uncoupling mitochondria proton transport from respiration (Liu et al., 2006; Klotzsch et al., 2015).

\section{NR4A1 transactivation domain was required to elicit mitochondrial proton leak}

To monitor mitochondrial membrane potential that depends on the mitochondrial proton gradient, we used time-lapse imaging of the potentiometric mitochondrial dye TMRM in neurons (Fig. 6A). Compared with GFP, NR4A1 reduced the following: (1) mito-
B

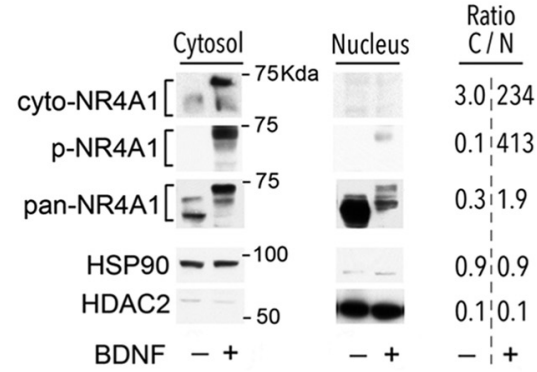

D

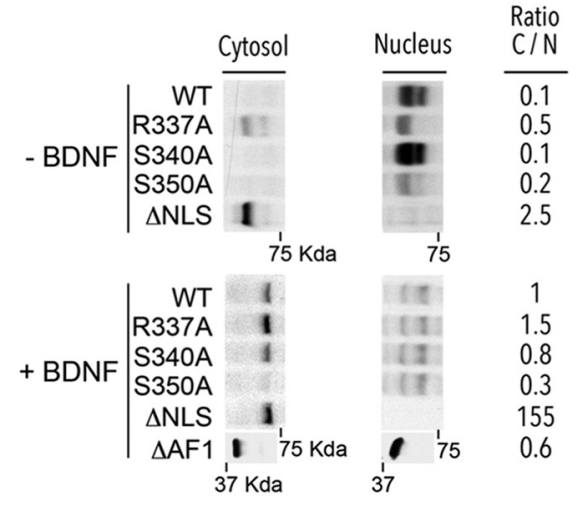

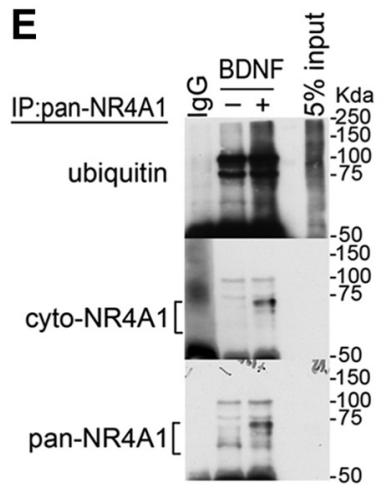

Figure 4. NR4A1 transcriptional activity in cortical neurons depends on its nuclear localization, phosphorylation, and turnover. $A$, NR4A1 activity expressed as a percentage of untreated controls impeded after stimulation with $25 \mathrm{ng} / \mathrm{ml} \mathrm{BDNF}$ for $3 \mathrm{~h}$ (mean \pm SEM of four independent experiments; unpaired $t$ test, ${ }^{*} p=0.042$ ). NurRE-Luc reporter was cotransfected with recombinant nucle0-cytoplasmic isoforms (pan-NR4A1), cytosolic isoform (cyto-NR4A1), and phosphorylated isoforms (p-NR4A1 at Ser350) of recombinant NR4A1 electroporated in primary cortical neurons. Ratio of proteins in cytosol (C) vs nuclear (N; means of four

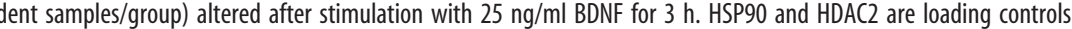
C, NurRE-Luc reporter activity in primary cortical neurons transfected with the indicated constructs. Data normalized to GFP controls (mean \pm SEM of three independent experiments; ANOVA post hoc Dunnett's test comparing WT and mutants, ${ }^{*} p<$ samples/group normalized to WT+BDNF). $\boldsymbol{E}$, Polyubiquitination of NR4A1 immunoprecipitated from lysates of primary cortical nant protein levels in primary cortical neurons. Mean \pm SEM of four independent experiments; ANOVA post hoc Sidak's test for interaction of BDNF and time, ${ }^{*} p<0.0001$.

chondrial membrane depolarization to glutamate (unpaired $t$ test: $\left.t_{(41)}=2.73, p=0.0091\right)$; (2) mitochondria membrane repolarization during washout (unpaired $t$ test: $t_{(41)}=3.05, p=0.0039$ ); and (3) mitochondria energetic competence in the oligomycin test (unpaired $t$ test: $t_{(18)}=2.27, p=0.035$ ) because it hyperpolarized mitochondria in GFP neurons but depolarized them in NR4A1-transfected neurons (Ward et al., 2000). These observations (Fig. $6 B$ ) indicated that NR4A1, unlike its mutant $\Delta \mathrm{AF} 1$, caused mitochondrial uncoupling.

Stimulation with glutamate decreased whole-cell ATP levels (main effect of glutamate: $-59 \pm 2.9 \%$; two-way ANOVA: $F_{(1,10)}=$ $106.8, p<0.0001$; post hoc Bonferroni's test: $p=0.0007)$. This use 


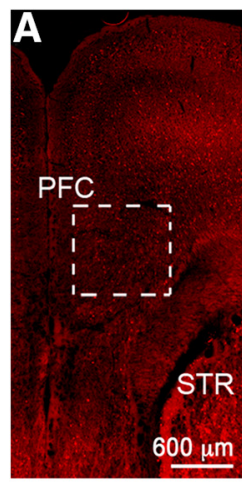

B

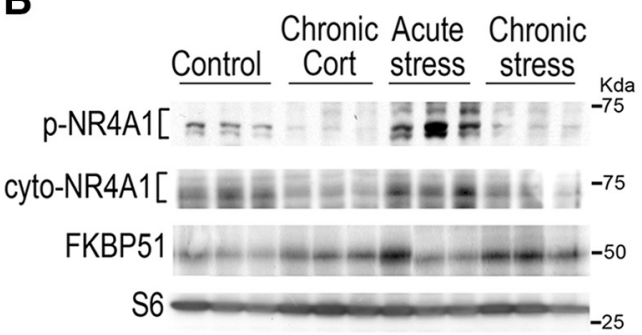

D

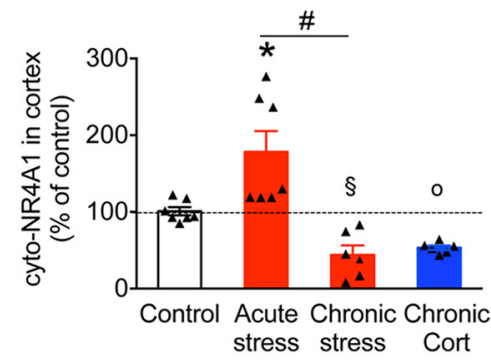

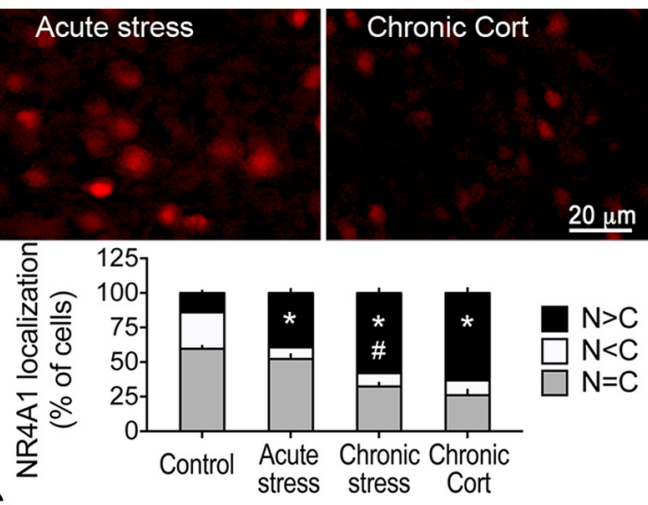

C

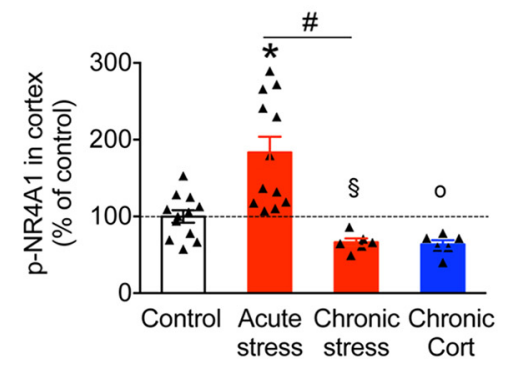

E

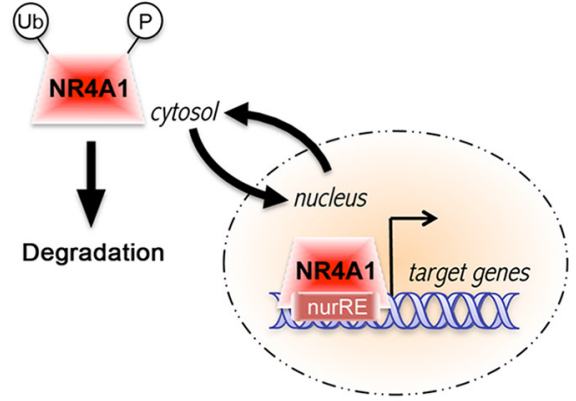

Figure 5. Chronic activation of the glucocorticoid stress pathway decreased NR4A1 phosphorylation and cytosolic distribution in mouse PFC. $A$, Endogenous NR4A1 protein is both nuclear and cytosolic in pyramidal cortical neurons of PFC (thy1-YFP). Proportion of a total of 10,600 cells with NR4A1 localized equally in nucleus and cytosol ( $N=C$ ), more in nucleus than cytosol ( $N>C$ ), and less in nucleus than cytosol $\left(\mathrm{N}<\mathrm{C}\right.$ ). Mean \pm SEM of $N=10$ controls, $N=10$ acute stress mice, $N=7$ CORT mice, and $N=9$ chronic stress mice; unpaired $t$ test: ${ }^{*} p=<0.0001$ comparing indicated group to controls; and \#p $=0.0006$ comparing acute to chronic stress mice. $\boldsymbol{B}$, Western blots of PFC lysates from P31 mice subjected to acute stress, chronic stress, or CORT injections compared with controls. C, Phosphorylation of NR4A1 (S350-P) expressed as a percentage of controls. Mean \pm SEM of $N=12$ control mice, $N=12$ acute stress mice, $N=6$ CORT mice, and $N=$ 6 chronic stress mice; unpaired $t$ test: ${ }^{*} p=0.013,0 p=0.0094, \S p=0.014$ comparing indicated treatment to controls; $\# p=0.0153$ comparing acute and chronic stress mice. $D$, Cytosolic NR4A1 expressed as a percentage of controls. Mean \pm SEM of $N=7$ control mice, $N=7$ acute stress mice, $N=6$ CORT mice, and $N=6$ chronic stress mice; unpaired $t$ test: ${ }^{*} p=0.025,0 p<0.0001$, $\S p=0.0009$ comparing indicated treatment to controls; $\# p=0.0025$ comparing acute and chronic stress mice. $E$, Model of NR4A1 functional transport in cortical neurons. Induction of NR4A1 by acute stress increased nuclear export and phosphorylation. Chronic stress prolonged NR4A1 nuclear residency, which failed to contain its activity.

Table 1. Effect of neuronal NR4A1 on mitochondria-regulatory gene expression

\begin{tabular}{|c|c|c|c|c|c|c|c|c|c|c|c|c|c|c|c|c|}
\hline & \multicolumn{16}{|c|}{ Treatments } \\
\hline & \multicolumn{2}{|l|}{ DRP1 } & \multicolumn{2}{|l|}{ MFN1 } & \multicolumn{2}{|l|}{ MFN2 } & \multicolumn{2}{|l|}{ FIS1 } & \multicolumn{2}{|l|}{ OPA1 } & \multicolumn{2}{|l|}{$U C P 2$} & \multicolumn{2}{|l|}{ UCP4 } & \multicolumn{2}{|l|}{ UCP5 } \\
\hline & $\%$ & SE & $\%$ & SE & $\%$ & SE & $\%$ & SE & $\%$ & SE & $\%$ & SE & $\%$ & SE & $\%$ & SE \\
\hline \multicolumn{17}{|l|}{ Ratio (NR4A1/GFP) } \\
\hline Untreated controls & 127.6 & 15.3 & 128.7 & 28.4 & 113.5 & 13.4 & 106.6 & 6.8 & 111.0 & 8.4 & $22.3^{* *}$ & 14.9 & $157.5^{* *}$ & 26.3 & 112.8 & 17.8 \\
\hline $25 \mathrm{ng} / \mathrm{ml} \mathrm{BDNF}$ & 119.5 & 16.9 & 132.3 & 22.0 & 104.8 & 11.9 & 97.9 & 8.8 & 75.7 & 8.3 & 87.4 & 10.6 & 126.4 & 16.2 & 77.8 & 11.8 \\
\hline 25 mm glutamate & 95.9 & 7.9 & 127.9 & 10.2 & 96.7 & 20.1 & 129.6 & 8.2 & 107.8 & 11.0 & 85.6 & 17.4 & 157.9 & 30.5 & 88.9 & 14.5 \\
\hline $100 \mathrm{~mm}$ glutamate & 121.3 & 16.6 & $70.1^{*}$ & 3.5 & 90.1 & 4.5 & $159.8^{*}$ & 20.7 & $155.5^{*}$ & 24.7 & 61.5 & 28.6 & $176.9^{*}$ & 14.9 & 98.2 & 9.2 \\
\hline
\end{tabular}

Messenger RNA levels determined by qPCR on total RNA extracts of primary cortical neurons (DIV14 with $10 \mathrm{~d}$ of doxycycline treatment). Data are expressed as a percentage of GFP controls (mean \pm SE of $N=4$ independent experiments). Unpaired $t$ test for comparing the effect of NR4A1 with GFP in untreated control cells. ${ }^{* *} p<0.036$, for comparing effect of NR4A1 with GFP in BDNF-treated cells ( $25 \mathrm{ng} / \mathrm{ml}$ for $3 \mathrm{~h}$ ). ${ }^{*} p<0.045$ for comparing the effect of NR4A1 with GFP in glutamate-treated cells $(100 \mu \mathrm{m}$ for $3 \mathrm{~h})$.

of ATP stocks was exaggerated by NR4A1 compared with GFP (unpaired $t$ test: $t_{(16)}=2.14, p=0.024$; Fig. $6 B$ ) but was far from the ATP-depleting effect of oligomycin (unpaired $t$ test: $t_{(10)}=3.17$, $p=0.009$; Fig. 6C). Consistent with a mild shortage of ATP, phosphorylation of the AMPK increased modestly by NR4A1 compared with GFP $\left(+33.8 \pm 5.2 \%\right.$; unpaired $t$ test: $t_{(31)}=5.55$, $p<0.0001$; Fig. $6 D$ ) and phosphorylation of its substrate ACC increased modestly by NR4A1 compared with GFP $(+34 \pm 7.8 \%$; unpaired $t$ test: $t_{(31)}=4.54, p<0.0001$; Fig. $\left.6 D\right)$. In contrast, $\Delta \mathrm{AF} 1$ lacking transcriptional activity had no effects on AMPK signaling. 


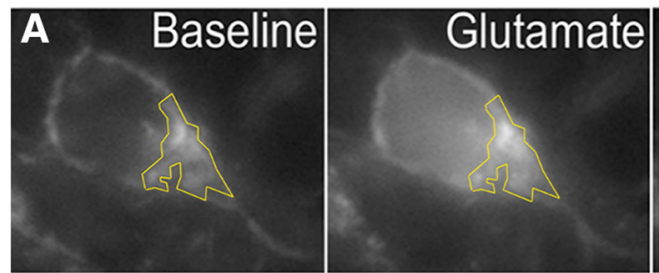

B

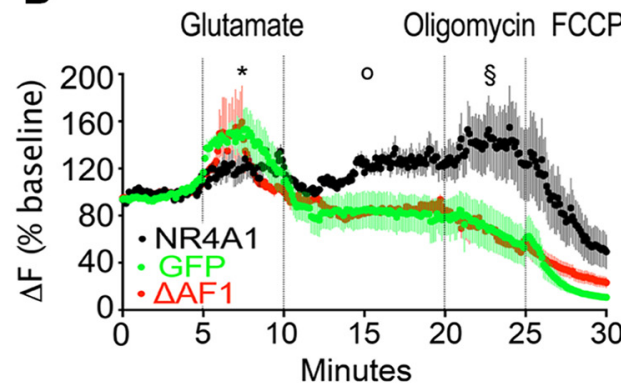

D

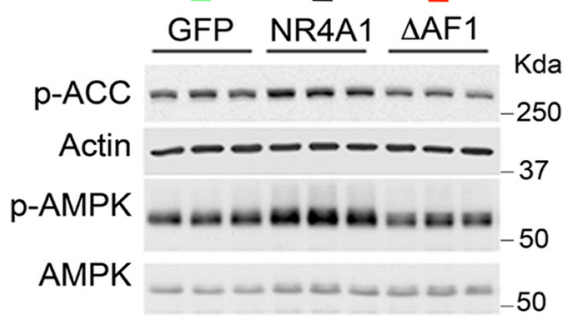

E

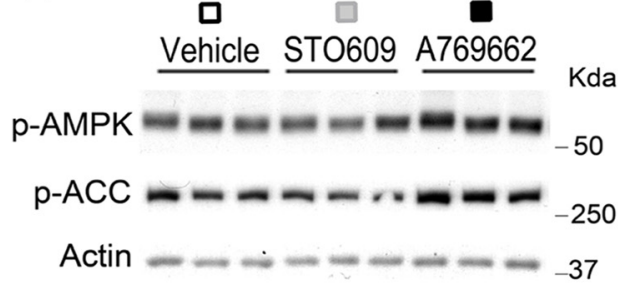

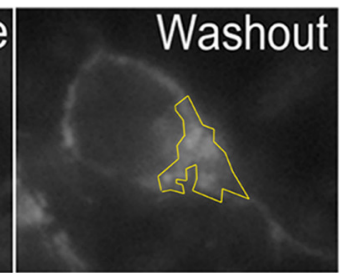

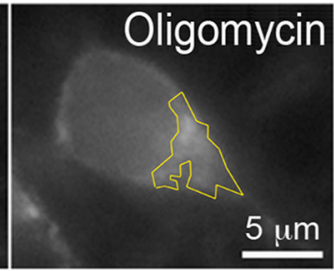

C
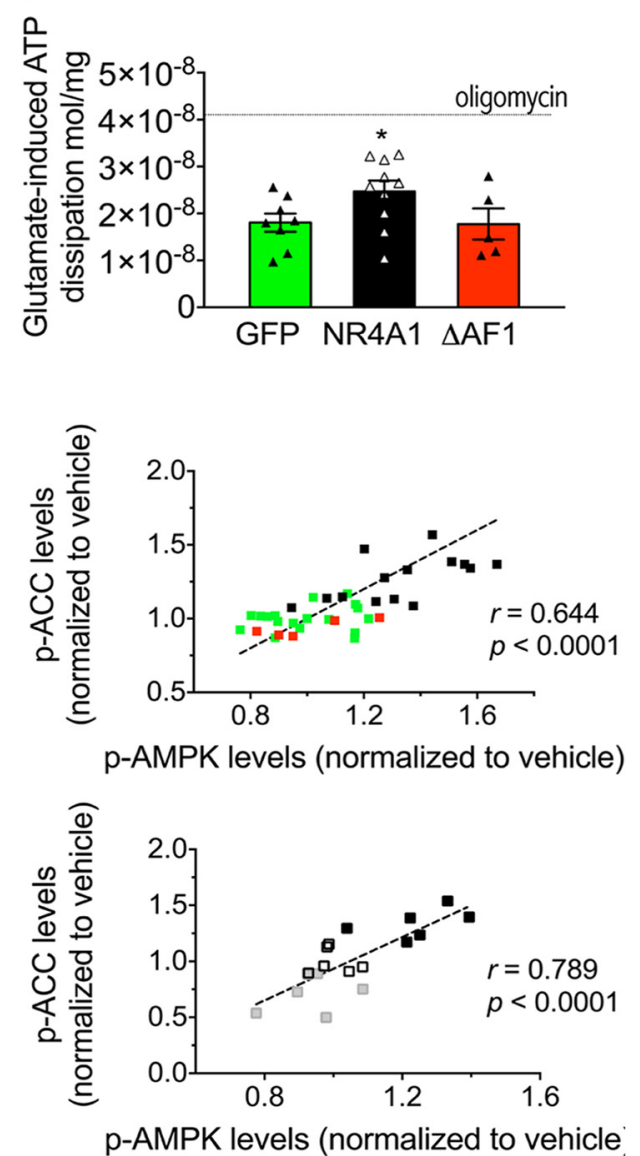

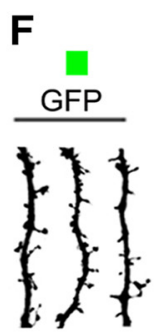

V S A

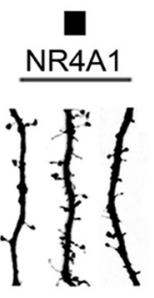

V S A
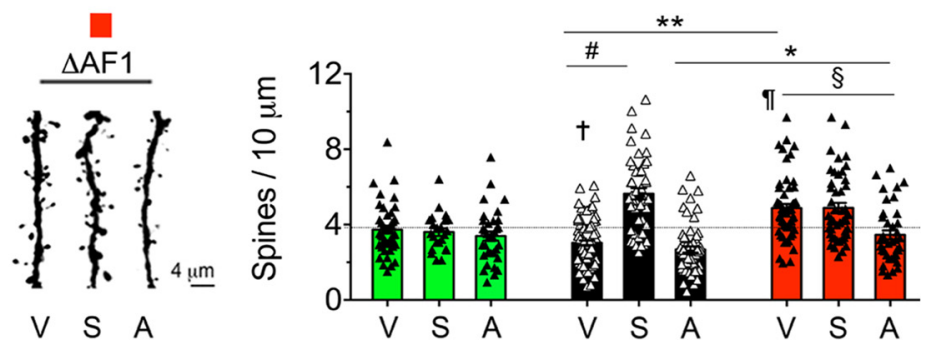

Figure 6. Activation of the NR4A1-AMPK pathway reduced dendritic spine number in vitro. $\boldsymbol{A}$, Time-lapse imaging of TMRM fluorescence in primary cortical neurons (DIV14 with $10 \mathrm{~d}$ of doxycycline treatment). Yellow box is one example of an ROI. $B, \Delta F\left(F-F_{0} / F_{0} \times 100\right)$ traces are the mean \pm SEM of $N=10 \mathrm{GFP}, N=10 \mathrm{NR} 4 \mathrm{~A} 1$, and $N=7 \Delta \mathrm{AF} 1 \mathrm{neurons}$ subjected to all treatments subsequently. Statistical comparison between GFP and NR4A1 groups at indicated epochs (last 3 min of each treatment) by unpaired $t$ test: during $100 \mu m$ glutamate, ${ }^{*} p=0.009$ ( $N=$ $16 \mathrm{GFP}, N=27$ NR4A1 cells); during washout, op $=0.0039$ ( $N=16 \mathrm{GFP}, N=27$ NR4A1 cells); and during $1 \mu \mathrm{m}$ oligomycin administration, $\$ p=0.035$ ( $N=10 \mathrm{GFP}, N=10 \mathrm{NR} 4 \mathrm{AA} 1$ cells). C, Dissipation of ATP upon stimulation of primary cortical neurons (DIV14 with $10 \mathrm{~d}$ of doxycycline treatment) with $100 \mu \mathrm{m}$ glutamate compared with $1 \mu \mathrm{M}$ oligomycin for $1 \mathrm{~h}$. Mean $\pm \mathrm{SEM}$ of $N=$ $8 \mathrm{GFP}, N=10 \mathrm{NR} 4 \mathrm{~A} 1$, and $N=5 \Delta \mathrm{AF} 1$ independent samples; unpaired $t$ test comparing GFP and NR4A1, ${ }^{*} p=0.024$. D, Phosphorylation of AMPK and its substrate ACC in primary cortical neurons (DIV14 with $10 \mathrm{~d}$ of doxycycline treatment) after stimulation with $25 \mu \mathrm{m}$ glutamate for $3 \mathrm{~h}(N=18 \mathrm{GFP}, N=15 \mathrm{NR} 4 \mathrm{~A} 1, N=5 \Delta \mathrm{AF} 1 \mathrm{samples} / \mathrm{group}$ ). Pearson correlation between levels of p-ACC and $p$-AMPK normalized to GFP as controls. Group comparison by unpaired $t$ test for $p$-ACC: NR4A1 vs GFP, $p<0.0001$; and $\Delta$ AF1 vs GFP, $p=0.009$; for $p$-AMPK: NR4A1 vs GFP, $p<0.0001$; and $\triangle \mathrm{AF1}$ vs GFP, $p=0.004$. E, Modulation of AMPK by $10 \mu \mathrm{M}$ ST0609 and $1 \mu \mathrm{M}$ A769662 for $24 \mathrm{~h}$ in primary cortical neurons (DIV14). Pearson correlation between levels of $p$-ACC and $p$-AMPK normalized to vehicle controls ( $N=6$ samples/group). Comparison by unpaired $t$ test for $p$-ACC: $S T 0609$ vs vehicle, $p=0.0061 ;$ and A769662 vs vehicle, $p=0.0007$; for $p$-AMPK: ST0609 vs vehicle, $p=0.2$; and A769662 vs vehicle; $p=0.0013$. F, Effect of ST0609 (S) and A769662 (A) compared with vehicle (V) on dendritic spine density in primary cortical neurons expressing GFP, NR4A1, or $\Delta$ AF1 (DIV21 with $10 \mathrm{~d}$ of doxycycline treatment). Mean \pm SEM of $N=99 \mathrm{GFP}, N=192 \mathrm{NR} 4 \mathrm{~A} 1$, and $N=160 \Delta$ AF1 dendrites; ANOVA post hoc Tukey's test for comparing the following: NR4A1 and $\Delta \mathrm{AF1},{ }^{* *} p<0.0001 ; \mathrm{GFP}$ and NR4A1, $\uparrow p=0.0019 ; \mathrm{GFP}$ and $\Delta \mathrm{AF1}, \mathbf{9} p=0.002 ;$ ST0609 and vehicle on NR4A1 cells, \#p <0.0001; A769662 and vehicle on $\Delta \mathrm{AF1}$ cells, $\$ p=0.023$; interaction of NR4A1 and A769662, ${ }^{*} p<0.045$. See extended data Figure 6-1 available at https://10.1523/JNEUROSCl.2793-17.2017.f6-1. 
A

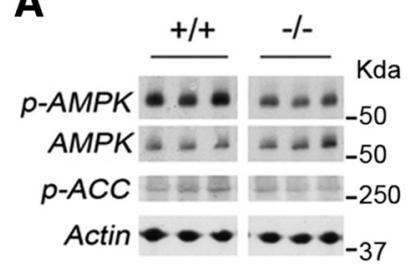

C

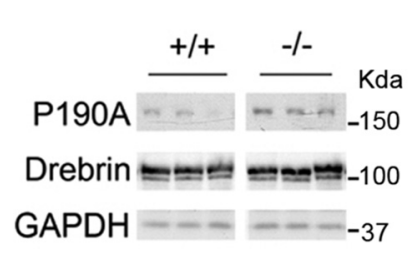

B
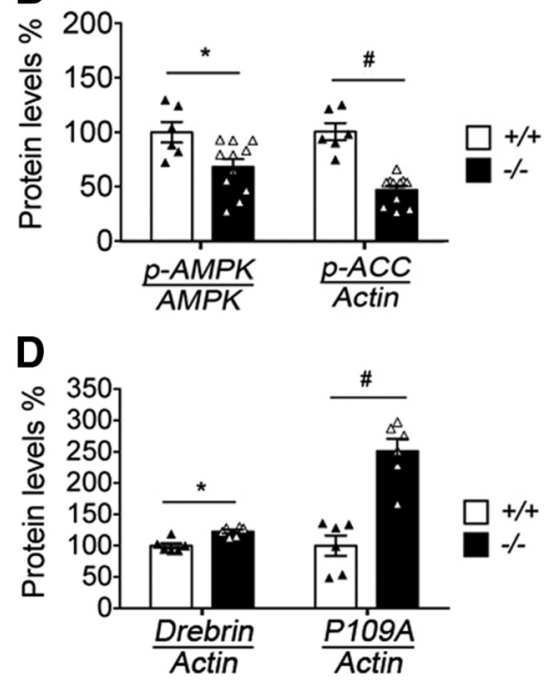

Figure 7. AMPK signaling and levels of synaptic markers in PFCs of NR4A1 knockouts. A, AMPK signaling in PFCs of NR4A1 KO rats. $\boldsymbol{B}$, Mean \pm SEM of $11-/-$ mice compared with $6+/+$ mice. Data expressed as a percentage of controls (unpaired $t$ test comparing genotypes: ${ }^{*} p=0.017$ and $\# p=0.007$ ). C, Levels of synaptic markers in PFCs of NR4A1 KO rats. $\boldsymbol{D}$, Mean \pm SEM of $6-1-$ mice compared with $6+1+$ mice. Data expressed as a percentage of controls (unpaired $t$ test comparing genotypes: ${ }^{*} p=0.0013$ and $\# p=0.0002$ ). See extended data Figure 7-1 available at https://10.1523/JNEUROSCI.2793-17.2017.f7-1.

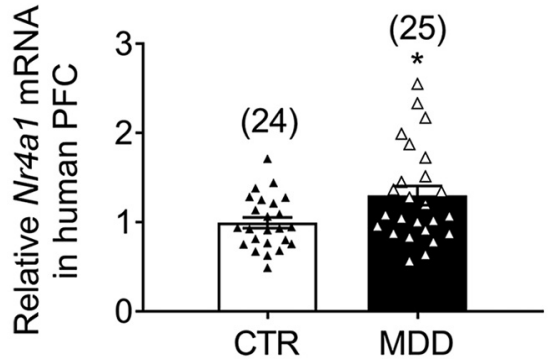

Figure 8. Abnormal NR4A1 transcript levels in human MDD brains. Upregulated levels of NR4A1 mRNA in PFCs of MDD subjects. Mean \pm SEM normalized to Tubulin ( $N=25$ CTR, $N=$ $24 \mathrm{MDD}$; unpaired $t$ test: $\left.t_{(47)}=3.13,{ }^{*} p=0.018\right)$. For demographic information, see extended data Figure 8-1 available at https://10.1523/JNEUROSCI.2793-17.2017.f8-1.

\section{NR4A1 used the AMPK catabolic pathway to reduce dendritic} spine number

To clarify a hypothetical link between AMPK signaling and morphological plasticity evoked by NR4A1, we used pharmacological modulators (Fig. 6E). We obtained mild modulation of AMPK in primary cortical neurons by STO609 $(-7 \pm 4.1 \%$ for p-AMPK and $-29 \pm 6.8 \%$ for p-ACC; unpaired $t$ test: $t_{(10)}=3.46, p=$ 0.006 ) and by $A 769662$ (p-AMPK: $+24.2 \pm 4.9 \%$; unpaired $t$ test, $t_{(10)}=4.43, p=0.0013$; p-ACC: $+33.8 \pm 5.3 \%$, unpaired $t$ test, $\left.t_{(10)}=4.79, p=0.0007\right)$, respectively, inhibitor of calcium/ calmodulin-dependent protein kinase kinase (CAMKK) activating kinase of AMPK (Mairet-Coello et al., 2013) and activator of AMPK (Scott et al., 2014). In transfected neurons, we found a functional interaction between NR4A1 and STO609 that reverted the low dendritic spine number above control levels (main effect of constructs by two-way ANOVA: $F_{(2,296)}=12.06, p<0.0001$; main effect of STO609: $F_{(1,296)}=16.5, p<0.0001$; interaction of constructs and STO609: $F_{(2,296)}=21.28, p<0.0001$; post hoc Tukey's test for comparing STO609 and vehicle: on NR4A1 cells, $p<$ 0.0001 ; on $\Delta$ AF1 cells, $p>0.99$; on GFP cells, $p=0.99$; Fig. $6 F$; for cumulative distributions, see Fig. 6-1 available at https://10.1523/ JNEUROSCI.2793-17.2017.f6-1). Such an interaction was absent between $\Delta \mathrm{AF} 1$ and STO609, suggesting redundancy between the NR4A1 and AMPK pathways.

We tested further this hypothetical framework with the AMPK activator A769662, as it is predicted to reduce dendritic spine number in neurons expressing $\triangle \mathrm{AF} 1$ but not in neurons expressing NR4A1. We found no functional interaction between NR4A1 and A769662. On the contrary, $\mathrm{A} 769662$ reverted the effect of $\Delta \mathrm{AF} 1$ on dendritic spine number (main effect of constructs by two-way ANOVA: $F_{(2,300)}=22.8$, $p<0.0001$; main effect of A769662: $F_{(2,300)}=$ $14.03, p=0.0002$; interaction of constructs and A769662: $F_{(1,300)}=1.96, p=$ 0.14 ; post hoc Tukey's test for comparing A769662 and vehicle: on $\Delta$ AF1 cells, $p=$ 0.0039; on NR4A1 cells, $p=0.6$; on GFP cells, $p=0.79$; Fig. $6 F$; for cumulative distributions, see Fig. 6-1 available at https:// 10.1523/JNEUROSCI.2793-17.2017.f6-1).

To confirm in vivo the functional link between AMPK and NR4A1 pathways, we used NR4A1 knockouts (Fig. 7). An effect of genotype on $\mathrm{p}$-AMPK (unpaired $t$ test: $t_{(15)}=2.66, p=0.017$ ) and p-ACC was observed in the PFC (unpaired $t$ test: $\left.t_{(15)}=6.8, p=0.0074\right)$. An effect of genotype was also observed on the levels of protein markers of excitatory synapses (P190A: unpaired $t$ test, $t_{(10)}=4.42, p=0.0013$; Drebrin: unpaired $t$ test, $t_{(10)}=5.88, p=0.0002$; Fig. $\left.7 D\right)$. This is consistent with the decrease of protein markers of excitatory synapses in primary cortical neurons expressing NR4A1 compared with $\Delta \mathrm{AF} 1$ (Fig. 7-1 available at https://10.1523/JNEUROSCI.2793-17.2017. f7-1). Altogether, these data indicated that AMPK signaling is an effector pathway of NR4A1 that alters dendritic spine number.

\section{NR4A1 levels in human PFC of MDD patients}

Mechanistic data support a causative role of NR4A1 on synaptic loss in PFC neurons in the context of stress and disrupted CORT levels, as both increased its neuronal activity in animal models. In humans, synaptic loss in PFC neurons and disrupted CORT levels are established neuropathological features of MDDs that are consistent with a putative impaired activity of NR4A1 (Duman et al., 2016). In a previous study (Duric et al., 2010), we showed that $N r 4 a 1$ transcripts were upregulated by 1.72 -fold ( $p=0.029, t$ test corrected for false discovery rate) in a whole-genome microarray profiling of human hippocampus in MDDs. In the same human cohort (for demographic information, see Fig. 8-1 available at https://10.1523/JNEUROSCI.2793-17.2017.f8-1), we analyzed Nr4a1 mRNA levels in the medial PFC. Quantitative PCR analysis showed that $\mathrm{Nr} 4 \mathrm{a} 1$ transcripts were significantly higher in PFC of MDD subjects (increase, 1.39 -fold; unpaired $t$ test: $t_{(47)}=3.13$, $p=0.018$ ) when compared with matched psychiatrically healthy control subjects (Fig. 8). Factorial analysis revealed no effect of $\operatorname{sex}(p=0.372)$ and no effect of antidepressant medication prescription $(p=0.139)$.

\section{NR4A1 levels in human PFC of AD patients}

Similarities in AD and MDD with respect to volume reduction, neuronal atrophy, and loss of connectivity in PFC could underlie common deficits in intracellular signaling network (van Veluw et al., 2012; Sampath et al., 2017). Synaptic loss in PFC neurons and 
disrupted CORT levels are neuropathological features of cognitive deficits across disorders with overlap in the expression of clinical state, established in MDD and AD (Uylings and de Brabander, 2002; Knobloch and Mansuy, 2008; Lupien et al., 2009). This prompted us to assess NR4A1 levels in PFC of human subjects clinically diagnosed with $\mathrm{AD}$ and age-matched cognitive healthy control subjects (for demographic information, see Fig. 9-1 available at https://10.1523/JNEUROSCI.2793-17. 2 017 . f 9 - 1). We used Western blots to discriminate between pan-NR4A1 and cytoNR4A1 levels, as NR4A1 activity cannot be determined postmortem (Fig. 9A). Levels of pan-NR4A1 correlated with those of AMPK (Pearson $r=0.53, p=0.0003$; Fig. $9 B$ ). Higher levels of AMPK (unpaired $t$ test: $t_{(39)}=2.17, p=0.035$; Fig. $\left.9 C\right)$ and pan-NR4A1 (unpaired $t$ test: $t_{(39)}=2.31$, $p=0.025$; Fig. 9D) were found in $\mathrm{AD}$ patients compared with control subjects. But lower levels of cyto-NR4A1 were found in $\mathrm{AD}$ patients compared with control subjects (unpaired $t$ test: $t_{(39)}=2.34, p=0.024$; Fig. $9 E)$. These data provided a molecular signature (Fig. $9 F$ ) proportionate to cognitive scores on the MMSE test (for cyto-NR4A1: Pearson $r=-0.37, p=0.041$; pan-NR4A1: Pearson $r=0.36, p=0.019$; AMPK: Pearson $r=0.48, p=0.011$; Fig. 9- $1 B$ available at https://10.1523/JNEUROSCI.2793-17. 2 017 .f $9-1)$ and to the levels of synaptic markers (PSD-95: Pearson $r=-0.38, p=$ 0.013; Drebrin: Pearson $r=-0.44, p=$ 0.003; P190A: Pearson $r=-0.31, p=0.049$; Fig. $9-1 B$ available at https://10.1523/ JNEUROSCI.2793-17.2017.f9-1). Factorial analysis revealed no effect of sex on any markers (for details, see Fig. 9-1 B, $C$ available at https://10.1523/JNEUROSCI. 2 $793-17.2017 . \mathrm{f} 9-1)$.

\section{Discussion}

NR4A1 is a transcription factor that we found deregulated in PFC of animal models of stress and excessive CORT levels, and in humans in whom mental health diseases for which disrupted CORT levels and stress are established aggravating factors were diagnosed (de Quervain et al., 2004; Holsboer and Ising, 2010; Machado et al., 2014; Duman et al., 2016). Our study provides the first substantial support for an idea long speculated about. That is, dendritic spine excitatory synaptic reduction following chronic stress or disrupted CORT levels is a compensatory mechanism resulting from the overactivity of cortical networks (Popoli et al., 2011). Although synaptic attrition and reorganization might compromise cognitive functions (Sampath et al., 2017), it minimizes adverse effects that would otherwise result from the prolonged bioenergetics burden on neurons (Harris et al., 2012; Picard et al., 2014; Jeanneteau and Arango-Lievano, 2016). NR4A1 provides such a link and a mechanism for how chronic stress and chronic CORT exposure lead to dendritic spine loss in PFC. Our study demonstrated that NR4A1 uses its transcrip-

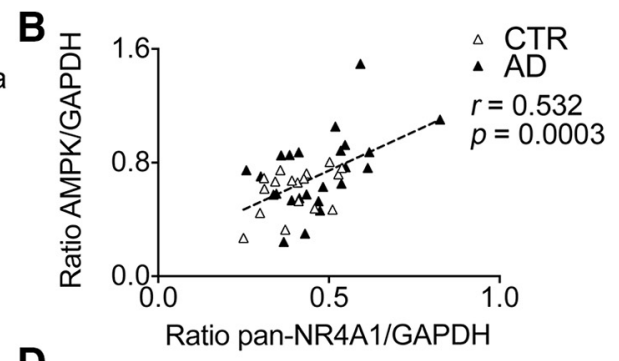

D

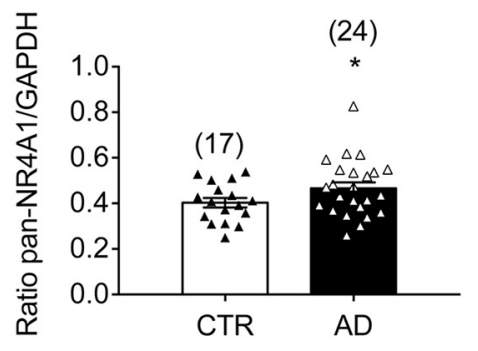

$\mathbf{F}$

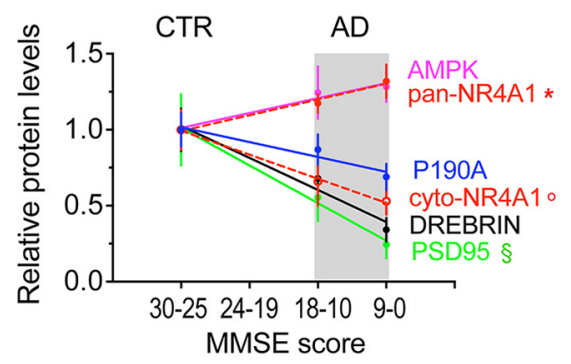

Figure 9. Abnormal levels of AMPK and NR4A1 in human AD brains. $\boldsymbol{A}$, Representative image of AMPK protein and NR4A1 nucley toplasmic isoforms in human cortex. See extended data Figure 9-1 available at https://10.1523/JNEUROSCI.2793-17 2017.f9-1. B, Pearson correlation ( $p=0.0003$ ) between AMPK and pan-NR4A1 levels in human PFCs from AD $(N=24)$ and CTR . Data are Western blot optical densities normalized to GAPDH. C, Upregulation of AMPK protein levels in human PFC Ded to GAPDH levels; unpaired $t$ test, ${ }^{*} p=0.024$ ). $E$, Upregulation of NR4A1 total isoforms in human PFCs (mean \pm SEM (be subjects and $N=17$ (TRs normalized to GAPDH levels; unpaired $t$ test, $\left.{ }^{*} p=0.0258\right)$. $F$, Pearson correlation

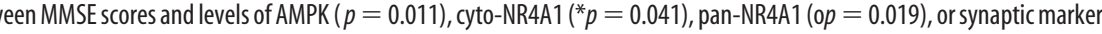
subje 0.013$)$, Drebrin $(p=0.003)$, and P190A ( $\# p=0.049$ ). Data are normalized to CTRs (mean \pm SEM of $N=17$ sujets with a score of $30-25, N=12$ subjects with a score of $18-10$, and $N=12$ subjec extended data Figure 9-1 available at https://10.1523/JNEUROSCI.2793-17.2017.f9-1.

tional activity to modify mitochondrial proton leak and dendritic spine number in cortical pyramidal neurons. Our study also provided evidence that neurotoxicity of chronic stress and CORT can be lessened by the knockdown and knockout of NR4A1 or partly counteracted by the molecular inactivation of NR4A1 with a dominant-negative approach.

\section{Adaptive response to protect neurons from damages of overexcitation}

As an activity-dependent immediate-early gene with high inducible pattern, high turnover rate, and an option for deactivation by nuclear export, NR4A1 presents with the necessary attributes to temporarily adjust cellular fate to the triggering stimulus (Maxwell and Muscat, 2006; Helbling et al., 2014). Such cell-autonomous and time-locked expression of NR4A1 should help to contain the neuronal damage from overexcitation by tempering the reception of excitatory signals and/or the response to such excitation. We found evidence supporting both possibilities, as NR4A1 reduced the number of excitatory synapses and the mitochondrial response to glutamate. Decreasing synapse number 
in pyramidal neurons could favor neuronal adaptation and behavioral flexibility when levels of glutamate and CORT are excessive in PFC (Popoli et al., 2011; Chattarji et al., 2015). Stressinduced atrophy of dendritic territories in PFC corresponded with aberrant levels of mitochondria-related proteins in synaptosomes and with cognitive impairment (Lopes et al., 2017). This extends previous findings in a model of epilepsy in which NR4A1 expression protected hippocampal neurons from seizure-induced damage by rendering mitochondria more resistant to cellular stress and by reducing neuronal excitability (Zhang et al., 2009).

\section{From adaptation to maladaptation}

NR4A1 expression in cortex and hippocampus responded to gradual acute stress but showed tolerance to chronic stress (Umemoto et al., 1994). The contrary was observed in other brain regions, indicating circuit specificity (Campos-Melo et al., 2011). This could result from differential epigenetic modifications at the $\mathrm{Nr} 4 a 1$ locus as a function of genetic background, development, and stressors (Kember et al., 2012; Mizuno et al., 2012; Tognini et al., 2015). The subcellular distribution of NR4A1 is also affected differently by acute and chronic stress even though the last stressor is the same, which suggests a change of tune in the immediate response to the stressor. This could be due to BDNF expression, which is subjected to opposite changes on acute and chronic stress (Bath et al., 2013; Jeanneteau and Chao, 2013), as it deactivates NR4A1 by way of nuclear export, phosphorylation, and downregulation by the ubiquitin-proteasome system. Nuclear retention of NR4A1 upon chronic stress is consistent with its prolonged activity that surpassed that induced by acute stress even though NR4A1 levels were higher in PFC neurons after acute rather than chronic stress. This is consistent with the low levels of cyto-NR4A1 despite the high levels of total NR4A1 found in PFCs of human subjects in whom AD has been diagnosed. Levels of cyto-NR4A1 also correlated with measures of synaptic markers and cognitive function. This is mirrored by the decreased expression of BDNF in the human AD brain (Ginsberg et al., 2017). However, both high and low levels of NR4A1 have been linked to mental health issues as cortical levels of NR4A1 were reported to be decreased in autism and schizophrenia (Corley et al., 2016; Li et al., 2016) and NR4A1 knockouts exhibit learning disabilities (McNulty et al., 2012) as well as transgenic mice with dominant-negative NR4A1 that showed defects of synaptic plasticity (Hawk et al., 2012; Bridi and Abel, 2013).

\section{A mechanistic framework to study signaling loops between mitochondria and synapses}

An important question raised by our study is to what extent the reduction of excitatory synapse number resulted from mitochondrial uncoupling. Manipulations of AMPK signaling established a functional link among NR4A1 transcriptional activity, AMPK, and excitatory synapses, which is corroborated by previous studies implicating AMPK in the regulation of synapse number, synaptic transmission, learning disabilities, and amyloid toxicity (Potter et al., 2010; Vingtdeux et al., 2011; Mairet-Coello et al., 2013; Ma et al., 2014). Uncoupling of mitochondrial respiration from proton transport resulted in a shortage of ATP stocks (Nicholls and Ward, 2000), activation of AMPK signaling (Weisová et al., 2012), and dendritic spine attrition (Dickey and Strack, 2011). We found that NR4A1 required its transcriptional activity to increase the proton leak in mitochondrial membranes and to increase ATP use in the context of glutamate stimulation. Previous studies showed that NR4A1 modulates mitochondria functions via genomic and nongenomic mechanisms (Close et al., 2013; Paw- lak et al., 2015). Thus, NR4A1 target genes are likely important for regulating metabolic and morphological aspects of neuronal functions. NR4A1 modified the expression of several mitochondria-regulatory genes, but only the $U C P s(U c p 2, U c p 4$, and $U c p 5)$ were countermodified by BDNF as it deactivated NR4A1. UCP4 dissipates transmembrane proton gradient in mitochondria to moderate respiration and to reduce reactive oxygen species damage from oxidative phosphorylation (Liu et al., 2006; Oita et al., 2009; Zhao and Bruemmer, 2010; Klotzsch et al., 2015). Previous silencing of UCP4 rendered mitochondria less resistant to glutamate excitotoxicity (Chan et al., 2006). Assuming that NR4A1dependent induction of UCP4 could decrease the dendritic spine number in the context of chronic stress and chronic CORT exposure, our study provides a mechanistic framework for investigating whether mitochondrial uncoupling could serve as a rheostat to isolate mitochondrial respiration from excessive excitatory stimulation that would endanger neuronal survival.

\section{Methodological limitations}

NR4A1 activity was not measured directly in human cortical tissues because it was not possible in postmortem biopsy samples. The monitoring of p-NR4A1 could have strengthened the other readouts (total protein or RNA levels and cyto-NR4A1) that only reflect NR4A1 activity indirectly. But we did not test for p-NR4A1 in human PFC tissues, as it could be equivocal in postmortem analysis. Previous study of fresh fibrotic tissues indicated that p-NR4A1 was inversely correlated with total NR4A1 levels and activity (Palumbo-Zerr et al., 2015), which is consistent with our findings in the human brain. The effect of medication on NR4A1 expression and activity is possible, but prescription medications were not disclosed as per HIPAA policies for a pathological study. The drugs used to manipulate AMPK activity provided only mild modulatory effects. But there are no direct inhibitors of AMPK that would suppress its activity or, currently, other activators specific and more potent than A769662 (Steinberg and Kemp, 2009; Scott et al., 2014). The magnitude of stress and CORT-mediated attrition of dendritic spines depends on age (Bloss et al., 2011; McEwen and Morrison, 2013). Our study investigated the PFCs of adolescent animals guided by previous reports in rodents of similar age subjected to similar procedures (Gourley et al., 2013; Swanson et al., 2013; Anderson et al., 2016). In particular, our studies were conducted on various animal species (KO mice and $\mathrm{KO}$ rats) and strains (C57BL/6 and $\mathrm{CD} 1$ ) by distinct investigators. Despite the heterogeneity of the models, knock-out, knock-down, and dominant-negative approaches all showed a role of NR4A1 in activating AMPK and reducing excitatory synapses number in cortex. The in utero electroporation system offered the advantages of unilateral targeting of sparse cortical neurons during embryogenesis, but impact on behavior was not informative. In contrast, constitutive knockouts exhibited a behavioral phenotype and permitted cross-validation of biochemical and morphological findings. Yet, NR4A1 is expressed in many cell types, which could bias the interpretations of KO data (Hawk and Abel, 2011; Safe et al., 2016). For instance, we found discrepancies in the effects of NR4A1 KO compared with its knockdown on dendritic spine number in PFC. Importantly, the hypothalamic-pituitary-adrenal axis signaling was normal in NR4A1-deficient mice, indicating that CORT secretion and response are not biased in this model (Crawford et al., 1995).

\section{Perspectives}

There is no known endogenous ligand for NR4A1 but synthetic ligands with agonistic and antagonistic properties are being de- 
veloped to regulate cellular fate in a variety of disease models (Safe et al., 2016). Drug-induced activation of NR4A1 to compensate for its low expression in a model of autism reduced the number of surplus synapses offering perspectives for therapeutic intervention (Li et al., 2016). There are also opportunities for clinical applications of NR4A1 ligands that would promote NR4A1 downregulation, nuclear export, or transcriptional blockade.

Note Added in Proof: One of the grants funding the work was accidentally not listed in the Early Release version published January 2, 2018. The funding information has now been corrected.

\section{References}

American Psychiatric Association (1994) Diagnostic and statistical manual of mental disorders: DSM-IV, Ed 4. Washington, DC: American Psychiatric Association.

Anderson RM, Glanz RM, Johnson SB, Miller MM, Romig-Martin SA, Radley JJ (2016) Prolonged corticosterone exposure induces dendritic spine remodeling and attrition in the rat medial prefrontal cortex. J Comp Neurol 524:3729-3746. CrossRef Medline

Arango-Lievano M, Lambert WM, Bath KG, Garabedian MJ, Chao MV, Jeanneteau F (2015) Neurotrophic-priming of glucocorticoid receptor signaling is essential for neuronal plasticity to stress and antidepressant treatment. Proc Natl Acad Sci U S A 112:15737-15742. CrossRef Medline

Arango-Lievano M, Peguet C, Catteau M, Parmentier ML, Wu S, Chao MV, Ginsberg SD, Jeanneteau F (2016) Deletion of neurotrophin signaling through the glucocorticoid receptor pathway causes tau neuropathology. Sci Rep 6:37231. CrossRef Medline

Attwell D, Laughlin SB (2001) An energy budget for signaling in the grey matter of the brain. J Cereb Blood Flow Metab 21:1133-1145. CrossRef Medline

Autry AE, Monteggia LM (2012) Brain-derived neurotrophic factor and neuropsychiatric disorders. Pharmacol Rev 64:238-258. CrossRef Medline

Bath KG, Schilit A, Lee FS (2013) Stress effects on BDNF expression: effects of age, sex, and form of stress. Neuroscience 239:149-156. CrossRef Medline

Bindokas VP, Lee CC, Colmers WF, Miller RJ (1998) Changes in mitochondrial function resulting from synaptic activity in the rat hippocampal slice. J Neurosci 18:4570-4587. Medline

Bloss EB, Janssen WG, Ohm DT, Yuk FJ, Wadsworth S, Saardi KM, McEwen BS, Morrison JH (2011) Evidence for reduced experience-dependent dendritic spine plasticity in the aging prefrontal cortex. J Neurosci 31 : 7831-7839. CrossRef Medline

Braak H, Braak E (1991) Neuropathological stageing of Alzheimer-related changes. Acta Neuropathol 82:239-259. CrossRef Medline

Bridi MS, Abel T (2013) The NR4A orphan nuclear receptors mediate transcription-dependent hippocampal synaptic plasticity. Neurobiol Learn Mem 105:151-158. CrossRef Medline

Calnan BJ, Szychowski S, Chan FK, Cado D, Winoto A (1995) A role for the orphan steroid receptor Nur77 in apoptosis accompanying antigeninduced negative selection. Immunity 3:273-282. CrossRef Medline

Campos-Melo D, Quiroz G, Noches V, Gysling K, Forray MI, Andrés ME (2011) Repeated immobilization stress increases nur77 expression in the bed nucleus of the stria terminalis. Neurotox Res 20:289-300. CrossRef Medline

Can A, Dao DT, Terrillion CE, Piantadosi SC, Bhat S, Gould TD (2012) The tail suspension test. J Vis Exp (59):e3769. CrossRef Medline

Cerqueira JJ, Taipa R, Uylings HB, Almeida OF, Sousa N (2007) Specific configuration of dendritic degeneration in pyramidal neurons of the medial prefrontal cortex induced by differing corticosteroid regimens. Cereb Cortex 17:1998-2006. CrossRef Medline

Chan RK, Brown ER, Ericsson A, Kovács KJ, Sawchenko PE (1993) A comparison of two immediate-early genes, c-fos and NGFI-B, as markers for functional activation in stress-related neuroendocrine circuitry. J Neurosci 13:5126-5138. Medline

Chan SL, Liu D, Kyriazis GA, Bagsiyao P, Ouyang X, Mattson MP (2006) Mitochondrial uncoupling protein-4 regulates calcium homeostasis and sensitivity to store depletion-induced apoptosis in neural cells. J Biol Chem 281:37391-37403. CrossRef Medline

Chao LC, Zhang Z, Pei L, Saito T, Tontonoz P, Pilch PF (2007) Nur77 coordinately regulates expression of genes linked to glucose metabolism in skeletal muscle. Mol Endocrinol 21:2152-2163. CrossRef Medline
Chattarji S, Tomar A, Suvrathan A, Ghosh S, Rahman MM (2015) Neighborhood matters: divergent patterns of stress-induced plasticity across the brain. Nat Neurosci 18:1364-1375. CrossRef Medline

Chen Y, Wang Y, Ertürk A, Kallop D, Jiang Z, Weimer RM, Kaminker J, Sheng M (2014) Activity-induced Nr4al regulates spine density and distribution pattern of excitatory synapses in pyramidal neurons. Neuron 83:431443. CrossRef Medline

Close AF, Rouillard C, Buteau J (2013) NR4A orphan nuclear receptors in glucose homeostasis: a minireview. Diabete Metab 39:478-484. CrossRef Medline

Corley SM, Tsai SY, Wilkins MR, Shannon Weickert C (2016) Transcriptomic analysis shows decreased cortical expression of NR4A1, NR4A2 and RXRB in schizophrenia and provides evidence for nuclear receptor dysregulation. PLoS One 11:e166944. CrossRef Medline

Counts SE, Nadeem M, Wuu J, Ginsberg SD, Saragovi HU, Mufson EJ (2004) Reduction of cortical TrkA but not p75(NTR) protein in early-stage Alzheimer's disease. Ann Neurol 56:520 -531. CrossRef Medline

Crawford PA, Sadovsky Y, Woodson K, Lee SL, Milbrandt J (1995) Adrenocortical function and regulation of the steroid 21-hydroxylase gene in NGFI-B-deficient mice. Mol Cell Biol 15:4331-4336. CrossRef Medline

Datson NA, Speksnijder N, Mayer JL, Steenbergen PJ, Korobko O, Goeman J, de Kloet ER, Joëls M, Lucassen PJ (2012) The transcriptional response to chronic stress and glucocorticoid receptor blockade in the hippocampal dentate gyrus. Hippocampus 22:359-371. CrossRef Medline

Davis MI, Puhl HL 3rd (2011) Nr4a1-eGFP is a marker of striosome-matrix architecture, development and activity in the extended striatum. PLoS One 6:e16619. CrossRef Medline

de Quervain DJ, Poirier R, Wollmer MA, Grimaldi LM, Tsolaki M, Streffer JR, Hock C, Nitsch RM, Mohajeri MH, Papassotiropoulos A (2004) Glucocorticoid-related genetic susceptibility for Alzheimer's disease. Hum Mol Genet 13:47-52. CrossRef Medline

Dickey AS, Strack S (2011) PKA/AKAP1 and PP2A/B $\beta 2$ regulate neuronal morphogenesis via Drp1 phosphorylation and mitochondrial bioenergetics. J Neurosci 31:15716-15726. CrossRef Medline

Duman RS (2004) Neural plasticity: consequences of stress and actions of antidepressant treatment. Dialogues Clin Neurosci 6:157-169. Medline

Duman RS, Aghajanian GK, Sanacora G, Krystal JH (2016) Synaptic plasticity and depression: new insights from stress and rapid-acting antidepressants. Nat Med 22:238-249. CrossRef Medline

Duric V, Banasr M, Licznerski P, Schmidt HD, Stockmeier CA, Simen AA, Newton SS, Duman RS (2010) A negative regulator of MAP kinase causes depressive behavior. Nat Med 16:1328-1332. CrossRef Medline

Fassett MS, Jiang W, D'Alise AM, Mathis D, Benoist C (2012) Nuclear receptor Nr4al modulates both regulatory T-cell (Treg) differentiation and clonal deletion. Proc Natl Acad Sci U S A 109:3891-3896. CrossRef Medline

Feng G, Mellor RH, Bernstein M, Keller-Peck C, Nguyen QT, Wallace M, Nerbonne JM, Lichtman JW, Sanes JR (2000) Imaging neuronal subsets in transgenic mice expressing multiple spectral variants of GFP. Neuron 28:41-51. CrossRef Medline

Folstein MF, Folstein SE, McHugh PR (1975) “Mini-mental state". A practical method for grading the cognitive state of patients for the clinician. J Psychiatr Res 12:189-198. CrossRef Medline

Ginsberg SD, Hemby SE, Lee VM, Eberwine JH, Trojanowski JQ (2000) Expression profile of transcripts in Alzheimer's disease tangle-bearing CA1 neurons. Ann Neurol 48:77-87. CrossRef Medline

Ginsberg SD, Mufson EJ, Counts SE, Wuu J, Alldred MJ, Nixon RA, Che S (2010a) Regional selectivity of rab5 and rab7 protein upregulation in mild cognitive impairment and Alzheimer's disease. J Alzheimers Disease 22:631-639. CrossRef

Ginsberg SD, Alldred MJ, Counts SE, Cataldo AM, Neve RL, Jiang Y, Wuu J, Chao MV, Mufson EJ, Nixon RA, Che S (2010b) Microarray analysis of hippocampal CA1 neurons implicates early endosomal dysfunction during Alzheimer's disease progression. Biol Psychiatry 68:885-893. CrossRef Medline

Ginsberg SD, Malek-Ahmadi MH, Alldred MJ, Che S, Elarova I, Chen Y, Jeanneteau F, Kranz TM, Chao MV, Counts SE, Mufson EJ (2017) Selective decline of neurotrophin and neurotrophin receptor genes within CA1 pyramidal neurons and hippocampus proper: correlation with cognitive performance and neuropathology in mild cognitive impairment and Alzheimer's disease. Hippocampus. Advance online publication. Retrieved December 24, 2017. doi:10.1002/hipo.22802. CrossRef Medline

Goldwater DS, Pavlides C, Hunter RG, Bloss EB, Hof PR, McEwen BS, Mor- 
rison JH (2009) Structural and functional alterations to rat medial prefrontal cortex following chronic restraint stress and recovery. Neuroscience 164:798-808. CrossRef Medline

Gourley SL, Swanson AM, Koleske AJ (2013) Corticosteroid-induced neural remodeling predicts behavioral vulnerability and resilience. J Neurosci 33:3107-3112. CrossRef Medline

Gray JD, Kogan JF, Marrocco J, McEwen BS (2017) Genomic and epigenomic mechanisms of glucocorticoids in the brain. Nat Rev Endocrinol 13:661-673. CrossRef Medline

Harris JJ, Jolivet R, Attwell D (2012) Synaptic energy use and supply. Neuron 75:762-777. CrossRef Medline

Hawk JD, Abel T (2011) The role of NR4A transcription factors in memory formation. Brain Res Bull 85:21-29. CrossRef Medline

Hawk JD, Bookout AL, Poplawski SG, Bridi M, Rao AJ, Sulewski ME, Kroener BT, Manglesdorf DJ, Abel T (2012) NR4A nuclear receptors support memory enhancement by histone deacetylase inhibitors. J Clin Invest 122:3593-3602. CrossRef Medline

Hazel TG, Misra R, Davis IJ, Greenberg ME, Lau LF (1991) Nur77 is differentially modified in PC12 cells upon membrane depolarization and growth factor treatment. Mol Cell Biol 11:3239-3246. CrossRef Medline

Heim C, Binder EB (2012) Current research trends in early life stress and depression: review of human studies on sensitive periods, gene-environment interactions, and epigenetics. Exp Neurol 233:102-111. CrossRef Medline

Helbling JC, Minni AM, Pallet V, Moisan MP (2014) Stress and glucocorticoid regulation of NR4A genes in mice. J Neurosci Res 92:825-834. CrossRef Medline

Holsboer F, Ising M (2010) Stress hormone regulation: biological role and translation into therapy. Annu Rev Psychol 61:81-109, C1-11. CrossRef Medline

Hyman BT, Trojanowski JQ (1997) Consensus recommendations for the postmortem diagnosis of Alzheimer disease from the National Institute on Aging and the Reagan Institute Working Group on diagnostic criteria for the neuropathological assessment of Alzheimer disease. J Neuropathol Exp Neurol 56:1095-1097. CrossRef Medline

Jeanneteau F, Arango-Lievano M (2016) Linking mitochondria to synapses: new insights for stress-related neuropsychiatric disorders. Neural Plast 2016:3985063. CrossRef Medline

Jeanneteau F, Chao MV (2013) Are BDNF and glucocorticoid activities calibrated? Neuroscience 239:173-195. CrossRef Medline

Jeanneteau F, Garabedian MJ, Chao MV (2008) Activation of Trk neurotrophin receptors by glucocorticoids provides a neuroprotective effect. Proc Natl Acad Sci U S A 105:4862-4867. CrossRef Medline

Karatsoreos IN, McEwen BS (2011) Psychobiological allostasis: resistance, resilience and vulnerability. Trends Cogn Sci 15:576-584. CrossRef Medline

Katagiri Y, Takeda K, Yu ZX, Ferrans VJ, Ozato K, Guroff G (2000) Modulation of retinoid signalling through NGF-induced nuclear export of NGFI-B. Nat Cell Biol 2:435-440. CrossRef Medline

Kember RL, Dempster EL, Lee TH, Schalkwyk LC, Mill J, Fernandes C (2012) Maternal separation is associated with strain-specific responses to stress and epigenetic alterations to $\mathrm{Nr} 3 \mathrm{cl}$, Avp, and Nr4al in mouse. Brain Behav 2:455-467. CrossRef Medline

Kim JJ, Diamond DM (2002) The stressed hippocampus, synaptic plasticity and lost memories. Nat Rev Neurosci 3:453-462. Medline

Klotzsch E, Smorodchenko A, Löfler L, Moldzio R, Parkinson E, Schütz GJ, Pohl EE (2015) Superresolution microscopy reveals spatial separation of UCP4 and F0F1-ATP synthase in neuronal mitochondria. Proc Natl Acad Sci U S A 112:130-135. CrossRef Medline

Knobloch M, Mansuy IM (2008) Dendritic spine loss and synaptic alterations in Alzheimer's disease. Mol Neurobiol 37:73-82. CrossRef Medline

Krishnan V, Nestler EJ (2011) Animal models of depression: molecular perspectives. Curr Top Behav Neurosci 7:121-147. CrossRef Medline

Lambert WM, Xu CF, Neubert TA, Chao MV, Garabedian MJ, Jeanneteau FD (2013) BDNF-signaling rewrites the glucocorticoid transcriptome via glucocorticoid receptor phosphorylation. Mol Cell Biol 33:3700-3714. CrossRef Medline

Lee SL, Wesselschmidt RL, Linette GP, Kanagawa O, Russell JH, Milbrandt J (1995) Unimpaired thymic and peripheral T cell death in mice lacking the nuclear receptor NGFI-B (Nur77). Science 269:532-535. CrossRef Medline

Li H, Zhao P, Xu Q, Shan S, Hu C, Qiu Z, Xu X (2016) The autism-related gene SNRPN regulates cortical and spine development via controlling nuclear receptor Nr4a1. Sci Rep 6:29878. CrossRef Medline
Li Z, Okamoto K, Hayashi Y, Sheng M (2004) The importance of dendritic mitochondria in the morphogenesis and plasticity of spines and synapses. Cell 119:873-887. CrossRef Medline

Liston C, Cichon JM, Jeanneteau F, Jia Z, Chao MV, Gan WB (2013) Circadian glucocorticoid oscillations promote learning-dependent synapse formation and maintenance. Nat Neurosci 16:698-705. CrossRef Medline

Liu D, Chan SL, de Souza-Pinto NC, Slevin JR, Wersto RP, Zhan M, Mustafa K, de Cabo R, Mattson MP (2006) Mitochondrial UCP4 mediates an adaptive shift in energy metabolism and increases the resistance of neurons to metabolic and oxidative stress. Neuromolecular Med 8:389-414. CrossRef Medline

Lopes S, Teplytska L, Vaz-Silva J, Dioli C, Trindade R, Morais M, Webhofer C, Maccarrone G, Almeida OFX, Turck CW, Sousa N, Sotiropoulos I, Filiou MD (2017) Tau deletion prevents stress-induced dendritic atrophy in prefrontal cortex: role of synaptic mitochondria. Cereb Cortex 27:2580 2591. CrossRef Medline

Lupien SJ, McEwen BS, Gunnar MR, Heim C (2009) Effects of stress throughout the lifespan on the brain, behaviour and cognition. Nat Rev Neurosci 10:434-445. CrossRef Medline

Ma T, Chen Y, Vingtdeux V, Zhao H, Viollet B, Marambaud P, Klann E (2014) Inhibition of AMP-activated protein kinase signaling alleviates impairments in hippocampal synaptic plasticity induced by amyloid $\beta$. J Neurosci 34:12230-12238. CrossRef Medline

Machado A, Herrera AJ, de Pablos RM, Espinosa-Oliva AM, Sarmiento M, Ayala A, Venero JL, Santiago M, Villarán RF, Delgado-Cortés MJ, Argüelles S, Cano J (2014) Chronic stress as a risk factor for Alzheimer's disease. Rev Neurosci 25:785-804. CrossRef Medline

Mairet-Coello G, Courchet J, Pieraut S, Courchet V, Maximov A, Polleux F (2013) The CAMKK2-AMPK kinase pathway mediates the synaptotoxic effects of Abeta oligomers through Tau phosphorylation. Neuron 78:94108. CrossRef Medline

Maxwell MA, Muscat GE (2006) The NR4A subgroup: immediate early response genes with pleiotropic physiological roles. Nucl Recept Signal 4:e002. CrossRef Medline

McEwen BS, Morrison JH (2013) The brain on stress: vulnerability and plasticity of the prefrontal cortex over the life course. Neuron 79:16-29. CrossRef

McEwen BS, Bowles NP, Gray JD, Hill MN, Hunter RG, Karatsoreos IN, Nasca C (2015) Mechanisms of stress in the brain. Nat Neurosci 18: 1353-1363. CrossRef Medline

McKlveen JM, Myers B, Flak JN, Bundzikova J, Solomon MB, Seroogy KB, Herman JP (2013) Role of prefrontal cortex glucocorticoid receptors in stress and emotion. Biol Psychiatry 74:672-679. CrossRef Medline

McNulty SE, Barrett RM, Vogel-Ciernia A, Malvaez M, Hernandez N, Davatolhagh MF, Matheos DP, Schiffman A, Wood MA (2012) Differential roles for Nr4a1 and Nr4a2 in object location vs. object recognition longterm memory. Learn Mem 19:588-592. CrossRef Medline

Meinke G, Sigler PB (1999) DNA-binding mechanism of the monomeric orphan nuclear receptor NGFI-B. Nat Struct Biol 6:471-477. CrossRef Medline

Mizuno K, Dempster E, Mill J, Giese KP (2012) Long-lasting regulation of hippocampal Bdnf gene transcription after contextual fear conditioning. Genes Brain Behav 11:651-659. CrossRef Medline

Myers B, McKlveen JM, Herman JP (2014) Glucocorticoid actions on synapses, circuits, and behavior: implications for the energetics of stress. Front Neuroendocrinol 35:180-196. CrossRef Medline

Nestler EJ, Hyman SE (2010) Animal models of neuropsychiatric disorders. Nat Neurosci 13:1161-1169. CrossRef Medline

Nicholls DG, Ward MW (2000) Mitochondrial membrane potential and neuronal glutamate excitotoxicity: mortality and millivolts. Trends Neurosci 23:166-174. CrossRef Medline

Oita RC, Mazzatti DJ, Lim FL, Powell JR, Merry BJ (2009) Whole-genome microarray analysis identifies up-regulation of $\mathrm{Nr} 4$ a nuclear receptors in muscle and liver from diet-restricted rats. Mech Ageing Dev 130:240-247. CrossRef Medline

Palumbo-Zerr K, Zerr P, Distler A, Fliehr J, Mancuso R, Huang J, Mielenz D, Tomcik M, Fürnrohr BG, Scholtysek C, Dees C, Beyer C, Krönke G, Metzger D, Distler O, Schett G, Distler JH (2015) Orphan nuclear receptor NR4A1 regulates transforming growth factor-beta signaling and fibrosis. Nat Med 21:150-158. CrossRef Medline

Pawlak A, Strzadala L, Kalas W (2015) Non-genomic effects of the NR4A1/ 
Nur77/TR3/NGFIB orphan nuclear receptor. Steroids 95:1-6. CrossRef Medline

Picard M, McEwen BS (2014) Mitochondria impact brain function and cognition. Proc Natl Acad Sci U S A 111:7-8. CrossRef Medline

Picard M, Juster RP, McEwen BS (2014) Mitochondrial allostatic load puts the "gluc" back in glucocorticoids. Nat Rev Endocrinol 10:303-310. CrossRef Medline

Pittenger C, Duman RS (2008) Stress, depression, and neuroplasticity: a convergence of mechanisms. Neuropsychopharmacology 33:88-109. CrossRef Medline

Popoli M, Yan Z, McEwen BS, Sanacora G (2011) The stressed synapse: the impact of stress and glucocorticoids on glutamate transmission. Nat Rev Neurosci 13:22-37. CrossRef Medline

Potter WB, O'Riordan KJ, Barnett D, Osting SM, Wagoner M, Burger C, Roopra A (2010) Metabolic regulation of neuronal plasticity by the energy sensor AMPK. PLoS One 5:e8996. CrossRef Medline

Radley JJ, Rocher AB, Miller M, Janssen WG, Liston C, Hof PR, McEwen BS, Morrison JH (2006) Repeated stress induces dendritic spine loss in the rat medial prefrontal cortex. Cereb Cortex 16:313-320. CrossRef Medline

Radley JJ, Rocher AB, Rodriguez A, Ehlenberger DB, Dammann M, McEwen BS, Morrison JH, Wearne SL, Hof PR (2008) Repeated stress alters dendritic spine morphology in the rat medial prefrontal cortex. J Comp Neurol 507:1141-1150. CrossRef Medline

Safe S, Jin UH, Morpurgo B, Abudayyeh A, Singh M, Tjalkens RB (2016) Nuclear receptor 4A (NR4A) family-orphans no more. J Steroid Biochem Mol Biol 157:48-60. CrossRef Medline

Sampath D, Sathyanesan M, Newton SS (2017) Cognitive dysfunction in major depression and Alzheimer's disease is associated with hippocampalprefrontal cortex dysconnectivity. Neuropsychiatr Dis Treat 13:15091519. CrossRef Medline

Sapolsky RM (2015) Stress and the brain: individual variability and the inverted-U. Nat Neurosci 18:1344-1346. CrossRef Medline

Sapolsky RM, Krey LC, McEwen BS (1985) Prolonged glucocorticoid exposure reduces hippocampal neuron number: implications for aging. J Neurosci 5:1222-1227. Medline

Scott JW, Ling N, Issa SM, Dite TA, O’Brien MT, Chen ZP, Galic S, Langendorf CG, Steinberg GR, Kemp BE, Oakhill JS (2014) Small molecule drug A-769662 and AMP synergistically activate naive AMPK independent of upstream kinase signaling. Chem Biol 21:619-627. CrossRef Medline

Sotiropoulos I, Catania C, Pinto LG, Silva R, Pollerberg GE, Takashima A, Sousa N, Almeida OF (2011) Stress acts cumulatively to precipitate Alzheimer's disease-like tau pathology and cognitive deficits. J Neurosci 31: 7840-7847. CrossRef Medline

Steinberg GR, Kemp BE (2009) AMPK in Health and Disease. Physiol Rev 89:1025-1078. CrossRef Medline

Swanson AM, Shapiro LP, Whyte AJ, Gourley SL (2013) Glucocorticoid receptor regulation of action selection and prefrontal cortical dendritic spines. Commun Integr Biol 6:e26068. CrossRef Medline
Tang Y, Zucker RS (1997) Mitochondrial involvement in post-tetanic potentiation of synaptic transmission. Neuron 18:483-491. CrossRef Medline

Tognini P, Napoli D, Tola J, Silingardi D, Della Ragione F, D'Esposito M, Pizzorusso T (2015) Experience-dependent DNA methylation regulates plasticity in the developing visual cortex. Nat Neurosci 18:956-958. CrossRef Medline

Umemoto S, Kawai Y, Senba E (1994) Differential regulation of IEGs in the rat PVH in single and repeated stress models. Neuroreport 6:201-204. CrossRef Medline

Uylings HB, de Brabander JM (2002) Neuronal changes in normal human aging and Alzheimer's disease. Brain Cogn 49:268-276. CrossRef Medline

Vallès A, Boender AJ, Gijsbers S, Haast RA, Martens GJ, de Weerd P (2011) Genomewide analysis of rat barrel cortex reveals time- and layer-specific mRNA expression changes related to experience-dependent plasticity. J Neurosci 31:6140-6158. CrossRef Medline

van Riel E, Meijer OC, Steenbergen PJ, Joëls M (2003) Chronic unpredictable stress causes attenuation of serotonin responses in cornu ammonis 1 pyramidal neurons. Neuroscience 120:649-658. CrossRef Medline

van Veluw SJ, Sawyer EK, Clover L, Cousijn H, De Jager C, Esiri MM, Chance SA (2012) Prefrontal cortex cytoarchitecture in normal aging and Alzheimer's disease: a relationship with IQ. Brain Struct Funct 217:797-808. CrossRef Medline

Vingtdeux V, Davies P, Dickson DW, Marambaud P (2011) AMPK is abnormally activated in tangle- and pre-tangle-bearing neurons in Alzheimer's disease and other tauopathies. Acta Neuropathol 121:337-349. CrossRef Medline

Ward MW, Rego AC, Frenguelli BG, Nicholls DG (2000) Mitochondrial membrane potential and glutamate excitotoxicity in cultured cerebellar granule cells. J Neurosci 20:7208-7219. Medline

Weisová P, Anilkumar U, Ryan C, Concannon CG, Prehn JH, Ward MW (2012) 'Mild mitochondrial uncoupling' induced protection against neuronal excitotoxicity requires AMPK activity. Biochim Biophys Acta 1817:744-753. CrossRef Medline

Xu L, Anwyl R, Rowan MJ (1997) Behavioural stress facilitates the induction of long-term depression in the hippocampus. Nature 387:497-500. CrossRef Medline

Zhang L, Xie F, Zhang J, Dijke PT, Zhou F (2017) SUMO-triggered ubiquitination of NR4A1 controls macrophage cell death. Cell Death Differ 24:1530-1539. CrossRef Medline

Zhang SJ, Zou M, Lu L, Lau D, Ditzel DA, Delucinge-Vivier C, Aso Y, Descombes P, Bading H (2009) Nuclear calcium signaling controls expression of a large gene pool: identification of a gene program for acquired neuroprotection induced by synaptic activity. PLoS Genet 5:e1000604. CrossRef Medline

Zhao Y, Bruemmer D (2010) NR4A orphan nuclear receptors: transcriptional regulators of gene expression in metabolism and vascular biology. Arterioscler Thromb Vasc Biol 30:1535-1541. CrossRef Medline 